\title{
Synthesis, characterization and applications of poly-aliphatic amine dendrimers and dendrons
}

\author{
Syeda Shaista Gillani ${ }^{1,2} \cdot$ Munawar Ali Munawar $^{2} \cdot$ Khalid Mohammed Khan $^{3,4} \cdot$ Jamil Anwar Chaudhary $^{2,5}$
}

Received: 15 November 2019 / Accepted: 5 June 2020 / Published online: 17 June 2020

(C) Iranian Chemical Society 2020

\begin{abstract}
In the current era, the dendrimers have vast potential applications in the area of electronics, healthcare, pharmaceuticals, biotechnology, engineering products, photonics, drug delivery, catalysis, electronic devices, nanotechnologies and environmental issues. This review recaps the synthesis, characterization and applications of poly-aliphatic amine dendrimers.
\end{abstract}

Keywords Dendrons $\cdot$ Dendrimers $\cdot$ Synthesis $\cdot$ Characterizations $\cdot$ Electronic devices $\cdot$ Environmental $\cdot$ Catalysis $\cdot$ Drug delivery

\section{Introduction}

\section{Dendrimers and dendron}

The "dendrimer" term has been derived from the Greek word dendron, meaning "tree" or "branch", and meros meaning "part". The terms "Arboroles" and "cascade polymers" are also used for dendrimers. In 1978, Fritz Vögtle first time reported the synthesis of a dendrimer. In 1983, Tomalia et al. introduced, a novel class of dendrimers constructed with a blend of amines and amides. These polyamidoamine dendrimers are generally called PAMAM dendrimers [1-6]. Ever since, more than 100 dendritic structures have been designated to explore the improved properties and innovative applications in fields such as nano- and bio-technologies,

Syeda Shaista Gillani

shaistagillani@1gu.edu.pk; shaistaaligillani@gmail.com

1 Department of Chemistry, Lahore Garrison University, DHA Phase-VI, Lahore 54792, Pakistan

2 Institute of Chemistry, University of the Punjab, Lahore 54590, Pakistan

3 H. E. J, Research Institute of Chemistry, International Center for Chemical and Biological Sciences, University of Karachi, Karachi 75270, Pakistan

4 Department of Clinical Pharmacy, Institute for Research and Medical Consultations (IRMC), Imam Abdulrahman Bin Faisal University, Dammam 31441, Saudi Arabia

5 Chemistry Department, University of Management and Technology, Lahore 54770, Pakistan catalysis and materials science [7-15]. During the 1980s and 1990s, many dendrimers were designed by different researchers [2].

Figure 1 shows the well-defined structure of a dendrimer composed of various components:

a) Multiple reactive sites originate from the central core which further grows into branches layer-by-layer in a symmetric fashion to form dendrimer generations.

b) Terminal groups surfaces increases radially and provide platforms for the covalent add-on of multiple functions.

c) After third or fourth generation, internal cavities formed which give the dendrimers a circular shape.

The foremost part is the focal core, captures different chemical species which possess incomparable properties because of the distinctive nano-environment enclosed by various dendritic splitting.

Second part consists of different internal layers of iterating units provides a stretchy interstellar of dendritic constructing blocks, to capture numerous minor guest molecules.

Third part describing the dendrimer's macroscopic properties is composed of multivalent surface that can attach various functionalities to interact with the external environment [4].

Figure 2 shows the structure of a dendron in which focal point is a distinct chemically addressable group. Branches originate only to one direction. 


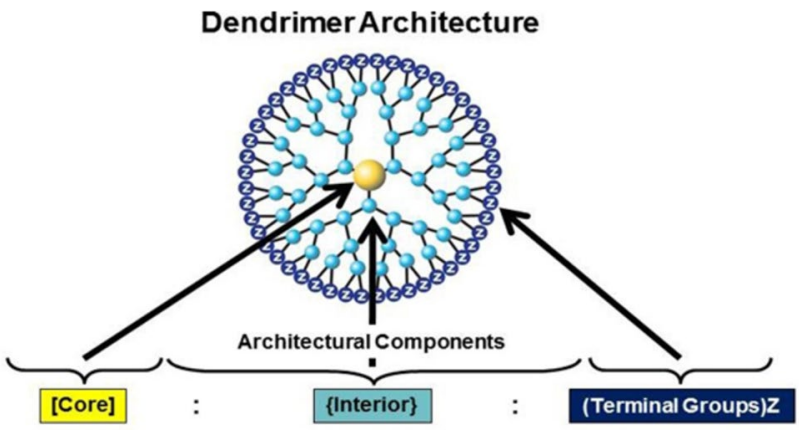

Fig. 1 Components of a dendrimer

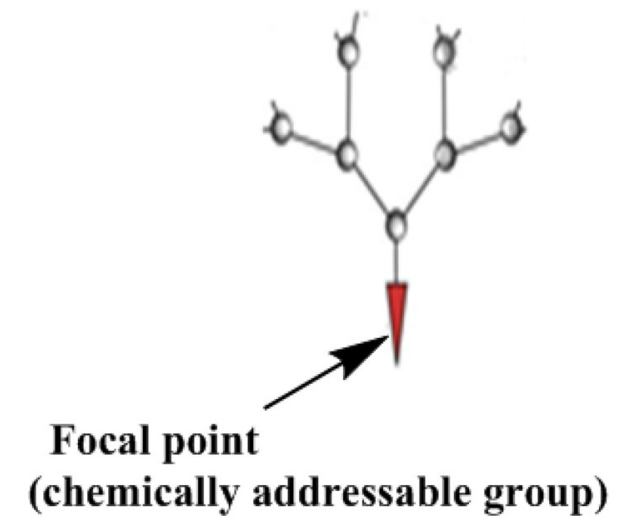

Fig. 2 Basic array of a dendron

\section{Terms and nomenclature used in dendrimer science}

A few terms and abbreviations utilized in the dendrimer science have been clarified. A brief structural classification has been depicted.

Hyperbranched polymers is a term clarifying a particular class of polymers typically get by incoherent polymerization of $\mathrm{AB}_{n}(n \geq 2)$ monomers, for the most part by one-pot reaction. Dendrimers have a place with an exceptional instance of hyperbranched polymers with an exact structure. To enhance the availability of dendritic assemblies, hyperbranched polymers are for sure reasons used as dendrimer "mimics", due to their more facile synthesis. In any case, being polydisperse, these sorts of polymers are not legitimate to analyze the chemical events taking place which for the most part need a specific constrained engineered topic empowering the master to examine the substance strategies happening. The physicochemical properties of the undefined hyperbranched polymers are at center between linear polymers and dendrimers as shown in Fig. 3 [16].

Dendrigrafts constitute a class of dendritic polymers just like dendrimers that can be worked with a well-described molecular structure, for instance being monodisperse. Be that as it may, as opposed to dendrimers, dendrigrafts are focused on linear polymer chain, to which branches including copolymer chains are attached. These copolymer chains are also changed with other copolymer chains, and so on, giving a hyperbranched substance created by a fixed number of joined polymers [17]. While the dendrimer look like a tree in structure, the central bit of a dendrigraft somewhat be like the structure of a palm-tree.

Dendrons are dendritic wedges with no center. The dendrimer can be synthesized by combining at least two dendrons. Dendrons are entirely significant tools in the synthesis of dendrimers by the convergent synthesis. A class of dendrons, monetarily open and has been used with multitudinous achievement in the covalent and non-covalent assembly of dendrimers, is known as the "Fréchet-type dendrons" [18-20]. These are dendritic wedges created by hyperbranched polybenzylether structure, similar to the Fréchet-type dendrimers. These dendrons have been used in the advancement of various dendrimers having different structures and capacities.

Generation is typical for all dendrimer designs and the hyperbranching when moving from the focal point of the dendrimer toward the edges, achieving homo-assistant layers between the focal core points. Generation number is the amount of focal centers climbing from the center towards the outside of a dendrimer. For example, a dendrimer having five focal centers when creating from the middle towards
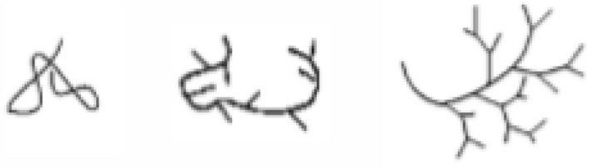

Linear
Branched
Hyperbranched

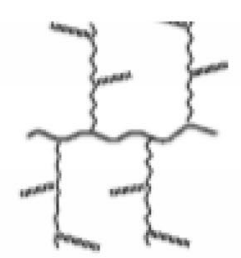

Dendrigraft

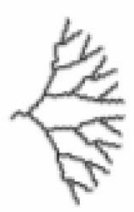

Dendrons

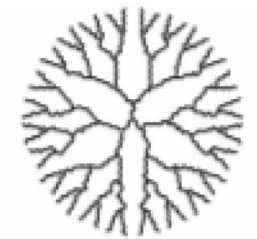

Dendrimers

Fig. 3 Evolution of linear polymers to dendritic assemblies 
the surface is the fifth-generation dendrimer and is abbreviated as G5-dendrimer, for instance fifth-generation polyamidoamine and polypropylene imine dendrimers can be compressed as "G5-PAMAM" and "G5-PPI" dendrimers independently. The focal point of the dendrimer is intermittently implied as zero generation or as "G0". The core structure having no focal centers, such as hydrogen substituents, cannot be considered as focal core points. Thus, in PPI dendrimers, 1,4-diaminobutane addresses the $\mathrm{G} 0$ focus structure and in PAMAM starburst dendrimers base addresses the G0 focus structure. Intermediates during the dendrimer association are so often implied as half-generation. A perceived model is the carboxylic finished PAMAM dendrimer which, would has properties attractive over the amino-terminated dendrimers when associated with normal structures.

Shell: The dendrimer shell is the "generation space" spatially separated between the focal core interests. The outside shell is the space between the end spreading point and the periphery. The inward shells are generally implied as the dendrimer interior.

Pincer: Dendrimer's external shell involves a variable number of pincers molded by the last focal point before moving to the dendrimer surface. In PPI and PAMAM dendrimers, the number of pincers is half the amount of terminal surface groups as in these dendrimers, the chain disconnects into two chains in each focal point.

End-group is normally referred as the "terminal group" or the "surface group" of the dendrimer. The word terminal is not as exact, as in the dendrimer branches can sometimes fold into the interior of the dendrimer. Dendrimers having amine terminal are named as "amino-terminated dendrimers".

Map dendrimer outlook for "multiple antigen peptide", is a dendron-like molecular create reliant on a polylysine skeleton. Lysine with its alkylamino side-chain serves as a good monomer for the introduction of numerous branching points. This sort of dendrimer was first reported by Tam in 1988 [21]. It has usage in biological applications, for instance, vaccine and diagnostic research. The main point is its exceptional structure, a "tree shaped" dendron without an inside. Nonetheless, whole dendrimer has been based upon this motif either by segmental coupling in solution using dendrons or stepwise by solid-phase synthesis.

PPI-dendrimers signify "poly(propylene imine)" depicting the propylamine spacer moieties in the dendrimer was developed initially by Buhleier et al. [22]. These dendrimers are typically poly-alkylamines having primary amines as surface groups. The dendrimer inside is made up of various tertiary tris-propylene amines. PPI dendrimers are commercially open up to generation five, and have found wide applications in material science. As an alternative name to PPI, POPAM is sometimes used to depict this class of dendrimers. POPAM stands to poly(propylene amine).
PEI-dendrimers are constitute a less standard sub-class of PPI dendrimers reliant on poly(ethylene imine) dendritic branches. In these dendrimers, diaminoethane or diaminopropane are the core structures.

PAMAM dendrimers stance for polyamido-amine, and refer to one of the sole dendrimer types made up of polyamide branches with tertiary amines as a middle point. After the initial report by Tomalia et al. [5, 23] in the mid1980s, PAMAM dendrimers have found wide use in science. PAMAM dendrimers are commercially available, usually as methanol solutions. The PAMAM dendrimers having end or surface amino groups (full generations) or carboxylic acid groups (half-generation) have been prepared. PAMAM dendrimers are commercially available up to G10 [18].

Starburst dendrimers is the trademark name for a subclass of PAMAM dendrimers reliant on a tris-aminoethylene-imine focus. The structures of such type of dendrimers appear star like when one looks structures of the high-generation dendrimers of this type in two dimension. These dendrimers are ordinarily known under the abbreviation PAMAM (Starburst) or just Starburst.

Fréchet-type dendrimers are the recent type of dendrimers made by Hawker and Fréchet [18-20] subject to a poly-benzylether hyperbranched skeleton. These kind of dendrimers can be symmetric or grown unevenly including 2 or 3 bits of segmental parts (dendrons) with, e.g. different generation or surface motif. These dendrimers usually have carboxylic acid groups as surface groups which act as anchoring points for further surface functionalization, and also help to increase the solubility of this hydrophobic dendrimer type in polar solvents or aqueous media.

Black ball: Due to the large molecular structure of a dendrimer, the full picture of reactions taking place on the dendrimer surface or in the outer shell could be difficult to depict. A way to facilitate the depiction of these macromolecules is by showing the inner (and unmodified) part of the dendrimer as a "black ball". Depending on whether the reaction takes place at the surface groups or in the outer shell, the appropriate part of the molecular motif, e.g. the outer pincers, may be fully drawn out to give a concise picture of a reaction involving the outer shell. In this way of reactions taking place at the dendrimer surface or in the outer shell is greatly simplified.

\section{Dendrimer design}

After the basic reports and improvement of these specific well-described structures, logical specialists have begun to develop excessive number of different designs of dendrimers for wider applications. Newkome and his group [24] have developed the unimolecular micelle consisting of an almost pure hydrocarbon scaffold. Majoral and Caminade have introduced the multivalent phosphorus to create intriguing 
new dendrimeric designs and dendrimers having new properties. Silicon and sulfur have also been participated in the dendritic structures resulting dendrimers having different properties from the conventional PAMAM and PPI designs [25]. The carbohydrates [26], amino acids [20] and nucleotides [27-29] have been applied as monomers also. Utilizing biological relevant monomers as building blocks presents an intriguing opportunity to incorporate biological recognition properties into the dendrimer [20,26]. Metals can serve as good focal points and have found extensive use in various functional dendrimer designs as well as in the synthesis of dendrimers by self-assembly [30].

\section{Synthetic methodologies for the dendrimer synthesis}

Two significant methodologies like divergent or convergent can be utilized to prepare dendrimers in contrast to the growth of direction. The divergent methodology (Fig. 4) was familiarized by Tomalia and Newkome $[2,31]$. The convergent methodology (Fig. 5) was presented by Hawker and Frechet $[19,32]$. The two methodologies supplement one another. Recently, a third methodology is introduced by Percec group [33] double-stage convergent-divergent strategy (Fig. 6).

In the early periods, unique methodology was used which is an inside-outward [34-36]. It begins to develop from the center of the dendrimer and arms are added by incorporating construction hinders in a complete and turning way. New monomer auxiliary can be introduced to the developing exterior of the circle in every age (Fig. 4). The proficiency of synthetic combination is fundamentally improved with the procedure of unique union. Unique union is routinely another alternative to direct amalgamation or focalized blend [37]. The main demerits of this methodology are the incomplete growth and the side reactions which lead to blemished dendrimers. The side reactions and imperfections can be minimized by using reagents in excessive amounts.

In the convergent methodology, the growth of dendrimers is from outward-in, wherein dendrons are coordinated regardlessly and are in this manner coupled to a spread center. It starts growing from the outward; begin with the molecular structure which finally transforms into the fringe arm of the end dendrimer (Fig. 5). In this procedure, the end generation number is pre-calculated, mixing the parts of a combination of basic dimensions up to this time for each generation [38].

The two methods have their own advantages and disadvantages. With an extension in the generation number of dendrimers using unique advancement, the amount of open end clusters at the periphery extends exponentially and it ends up being to an incredible degree difficult to motivate $100 \%$ change to get defect free dendrimers at larger generations. The cleansing of dendrimers winds up troublesome, and in like manner, an excess of reagents is required to change over different terminal groups. However, the

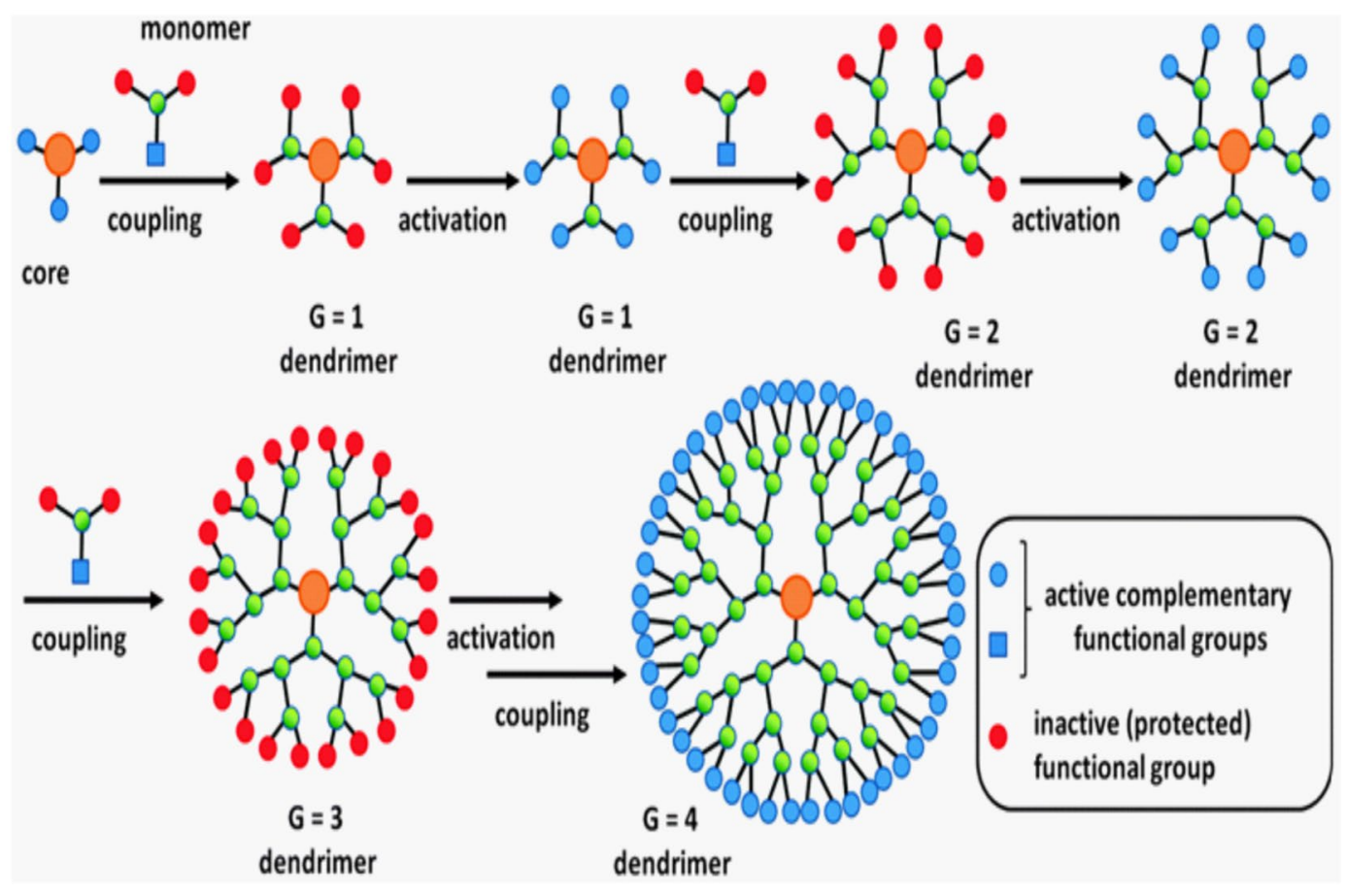

Fig. 4 Divergent synthetic method 


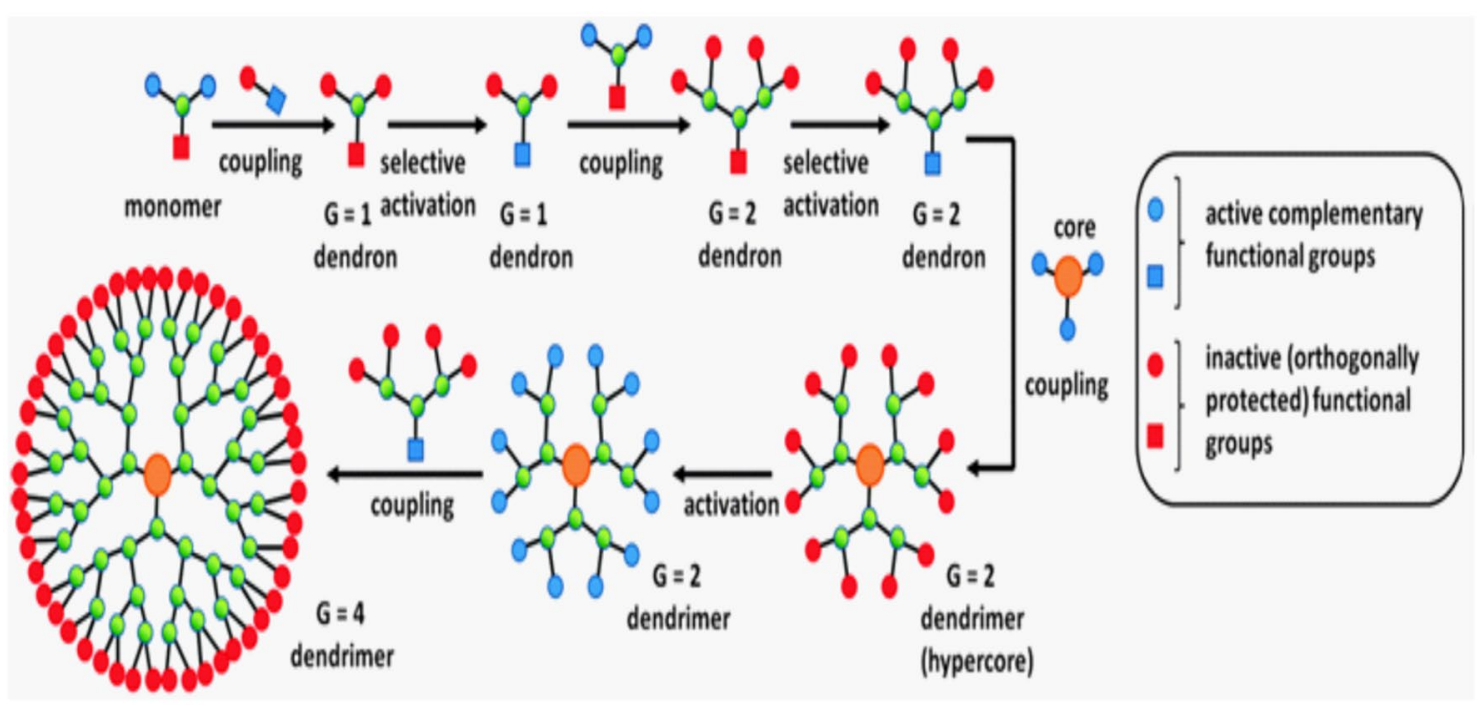

Fig. 5 Convergent synthetic method

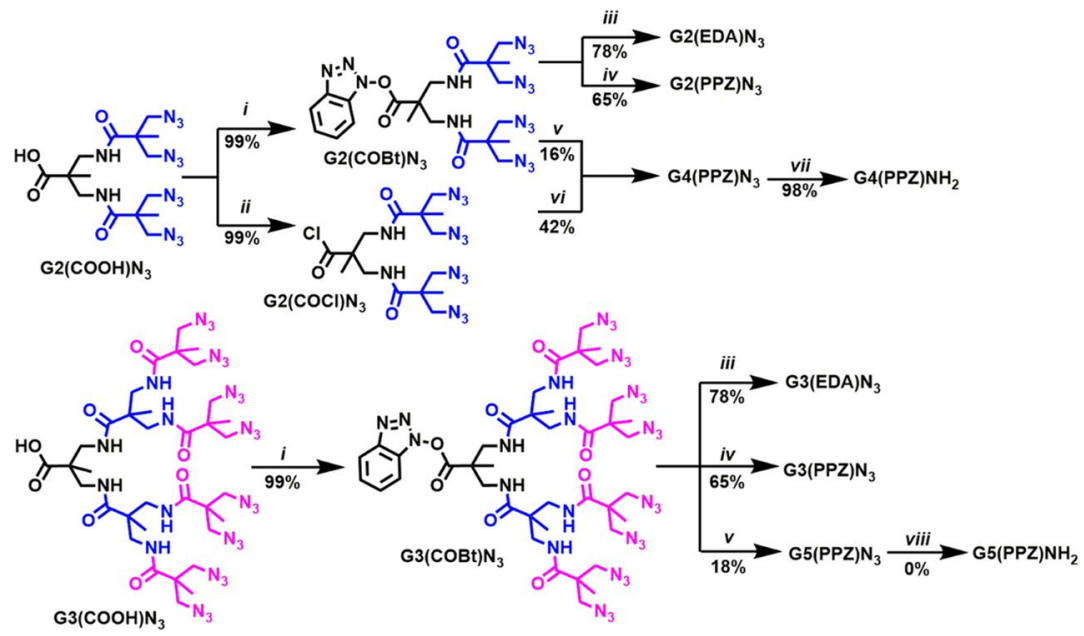

Reagents and conditions: (i) $\mathrm{HOBt}, \mathrm{DCC}, \mathrm{CH}_{2} \mathrm{Cl}_{2}, 23{ }^{\circ} \mathrm{C}, 1 \mathrm{~h}$, then $35^{\circ} \mathrm{C}, 5 \mathrm{~h}$; (ii) $\mathrm{SOCl}_{2}, \mathrm{CH}_{2} \mathrm{Cl}_{2}$, reflux, $4 \mathrm{~h}$; (iii) EDA, $\mathrm{Et}_{3} \mathrm{~N}, \mathrm{CH}_{2} \mathrm{Cl}_{2}, 23{ }^{\circ} \mathrm{C}, 24 \mathrm{~h}$; (iv) PPZ, $\mathrm{Et}_{3} \mathrm{~N}, \mathrm{CH}_{2} \mathrm{Cl}_{2}, 23{ }^{\circ} \mathrm{C}, 24 \mathrm{~h}$; (v) $\mathrm{G} 2(\mathrm{PPZ}) \mathrm{NH}_{2}, \mathrm{Et}_{3} \mathrm{~N}, \mathrm{CH}_{2} \mathrm{Cl}_{2}, 23{ }^{\circ} \mathrm{C}, 12 \mathrm{~h}$; (vi) G2(PPZ) $\mathrm{NH}_{2}, \mathrm{Et}_{3} \mathrm{~N}, \mathrm{CH}_{2} \mathrm{Cl}_{2},-78{ }^{\circ} \mathrm{C}, 0.5 \mathrm{~h}$, then $23{ }^{\circ} \mathrm{C}, 12 \mathrm{~h}$; (vii) $10 \% \mathrm{Pd} / \mathrm{C}$ [50\% (wt/wt)], $\mathrm{H}_{2}(120 \mathrm{psi}), 23$ ${ }^{\circ} \mathrm{C}, 8 \mathrm{~h}$; (viii) $10 \% \mathrm{Pd} / \mathrm{C}\left[80 \%\right.$ (wt/wt)], $\mathrm{H}_{2}(120 \mathrm{psi}), 23{ }^{\circ} \mathrm{C}, 8 \mathrm{~h}$.

Fig. 6 Combined divergent-convergent synthesis [33]

development can be controlled and stopped at any stage as demonstrated by the need of number of terminal groups and size of dendrimers using special procedures. The concurrent methodology, on the other hand, can create imperfection free dendrimers in view of the proximity of less number of end groups. As the dendrons are smaller in size, the cleansing is almost more straightforward [37].

In the combined convergent-divergent strategy, the synthesis of aliphatic polyamide dendrimers till G3 with EDA core and G5 with PPZ core have been achieved (Fig. 6) [33].
Polyamidoamine (PAMAM) dendrimers [5, 39] are one of the huge classes of dendrimers. The different arms in PAMAM dendrimers promote the availability and utilization of surface functionalities [40]. It is typically difficult to integrate monodisperse higher generation dendrimers with no cut arms. Therefore, as to propel the limit of dendrimer blend, a decrease in opportunity to integrate bigger generation, various techniques to diminish these combinations have been referred. These include two fold exponential development, two fold organize, hyper monomer, 
and symmetrical coupling systems. In this methodology, hyperbranched monomers [41, 42] (AB2) can be utilized to make bigger generation items in a less number of steps. Symmetrical functionalities utilized for AB2 type monomers can upgrade a few inadequacies forced by old style dendrimer union. However, a straightforward and reasonable engineered approach to aliphatic polyamide dendrimers utilizing AB2 hyper monomer has not yet been noted.

In the literature, different kinds of dendrimers and dendrons have been reported:

Tomalia et al. introduced the first family of dendrimers [43 and reference therein]. At that time, poly(amidoamine) (PAMAM) dendrimers with molecular weights ranging to 25,000 were prepared on a marketable scale.

The dendrimers shown in the (Fig. 7a, b) have been synthesized by the addition of the branches in the first step to methyl acrylate via exhaustive Michael addition followed by aminolysis. Ethylene diamine is a key core [44].

Literature reveal the synthesis of a number of aliphatic polyamide amine dendrimers shown in Fig. 8 [33 and references therein].

PAMAM dendrons based silica-coated magnetic nanoparticles have been synthesized (Fig. 9). The dendritic species have been claimed to show selectivity and greater reactivity for hydroformylation reactions [45].

Polyamide dendrimer with ethylene diamine (EDA) core has been synthesized to G3 by divergent method. The synthesis of dendrimers having 3,3'-diaminopivaloyl moieties involves the successive acylation-hydrogenation reactions. The generations of dendrimer have been grown by amide bond formation [46]. Figure 10 describes the strategy planned for construction of dendrimer containing two iterative steps: one involves the linkage between azide species and whichever the dendrimer center or terminal amino groups of the resultant dendrimer generation, accomplishing amide-connected multi-azides, and second involves the reduction of azide to amino structures. The linkage steps have been carried by straight forward techniques used in the condensation of carboxylic acids and amines. The reduction steps have been ideally accomplished by means of synergist hydrogenation conditions under $\mathrm{H}_{2}$ environment on $\mathrm{Pd} / \mathrm{C}$ in methanol.

Divergent synthesis of G4 dendrimer with an ethylene diamine (EDA) core has also been reported using the methodology reported earlier with some modifications (Fig. 11). The main modification was the use of $\mathrm{CH}_{2} \mathrm{Cl}_{2} /$ $\mathrm{Et}_{3} \mathrm{~N}$ solution at $0-23{ }^{\circ} \mathrm{C}$ in place of water/ $\mathrm{NaOH}$ in amidation steps. This change upgraded the yield of the amidation venture at all generation with a significant increment at G3 from 27 to 59\%. The other modification attempted was the use of 1-hydroxybenzotriazole (HOBt) derived activated esters in place of acid chlorides.

The same methodologies have also been applied to synthesize five-generation dendrimers with a piperazine (PPZ) core (Fig. 12). As compared to ethylenediamine (EDA) core that permitted the blend of just G4, the piperazine (PPZ) also delivered G5 dendrimer in good yields (44-38\%) using the both strategies.

The convergent synthesis of three generations, and the divergent synthesis of six generations of aliphatic polyamide dendrons (Fig. 13) have also been reported by the same group of researchers using the both acid chloride and benzotriazole ester pathways.

\section{Properties of dendrimers}

The nature of the terminal groups determined the chemical reactivity of dendrimers as well as their physical parameters such as chemical reactivity, solubility and glass transition temperature. This is because of the radially increase in number of terminal groups with the increase in generation number of the dendrimers in comparison to linear polymers having only two terminal groups [43, 47-50].

The gradual change in the shapes of dendrimer molecules from an extended arrangement for lower generation dendrimers to a globular shape for higher generation dendrimers may cause the deviation in physical behavior of dendrimers from those of linear macromolecules. The solubility of dendrimers is usually increased in connection to their generation numbers. Nevertheless, the reactivity and solubility of the dendrimers especially in case of globular shape molecules by the nature of the peripheral groups.[43, 47, 51, 52].

The volume of a dendrimer increases cubically while the molecular weight increases exponentially with upturn in generation number. This leads to deviation in solution properties of dendrimer molecules from those of linear macromolecules especially at higher molecular weights. The intrinsic viscosity is used to determine the extent of deviation in case of dendrimers in comparison to that of linear macromolecules. Usually, dendrimers have low intrinsic viscosity.[43, 47, 53-55]. Dendrimers have some interesting characteristics in contrast to classical polymers:

1) Low poly-dispersity.

2) Precise number of peripheral groups.

3) Nominal cell take-up.

4) The shape and size of dendrimers can be controlled at certain generation number.

5) Capacity of physical attachment to ligands and drug molecules is more.

6) Numerous dynamic sites.

7) Tailor made structure.

The number, nature and position of the peripheral groups which play a vital role to tailor the unique 
Fig. 7 a Divergent method for synthesis of polyaliphatic amido amine dendrimers (Tomalia). b $\mathrm{G}_{4}$ dendrimer with 64 amino groups at the periphery
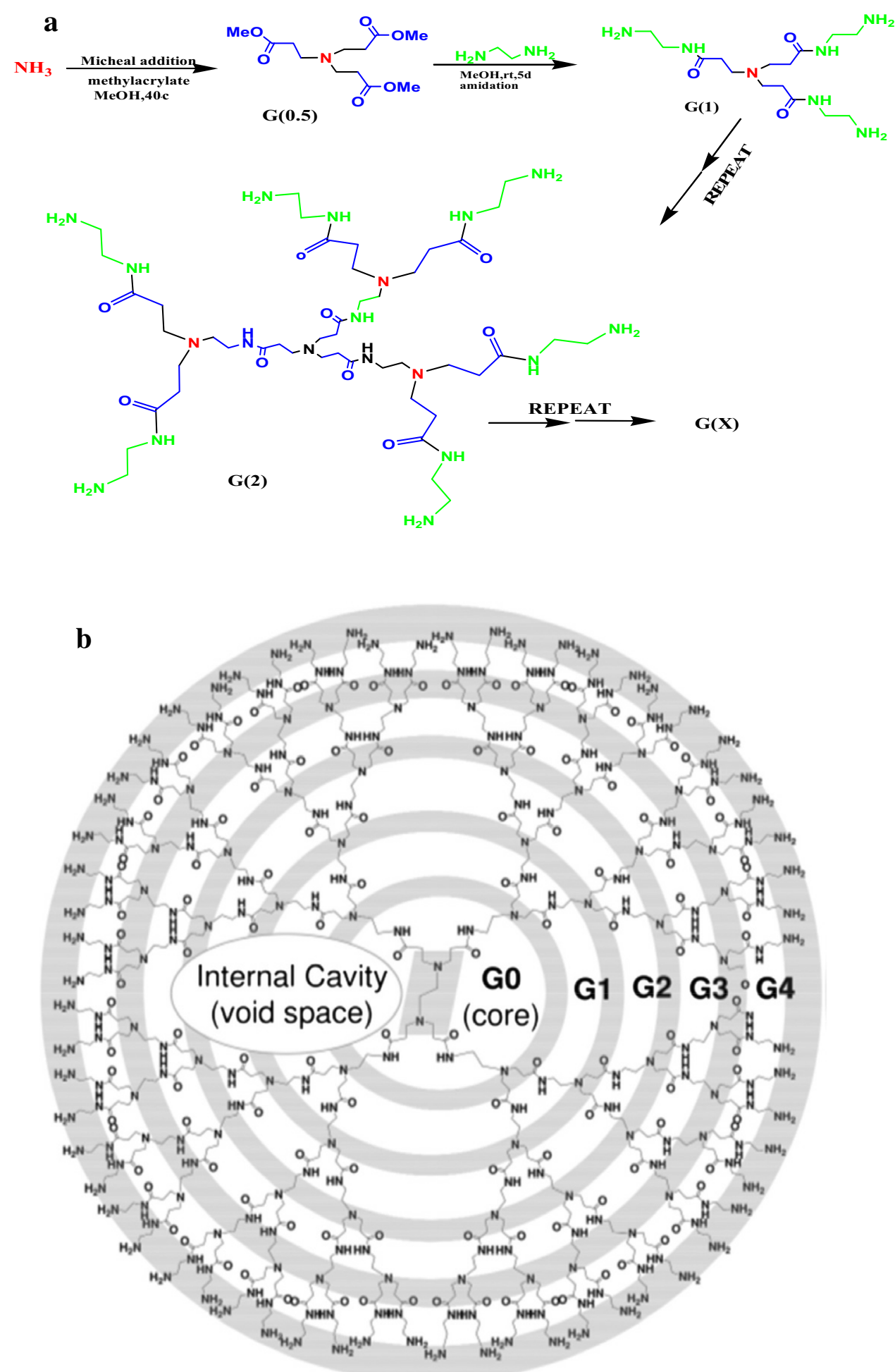

properties of a dendrimer. These properties include unparalleled molecular uniformity, multifunctional surface and the presence of internal cavities in addition to other specific properties to be suitable for a variety of high technology uses.

\section{Dendrimer applications}

The advances in the chemistry of dendrimer and the biomedical application have been carried out by a number of researchers like Astruc et al. [56], Smith and Diederich [57], Emrick and Fréchet [16], Frey and Schlenk [58], 
A

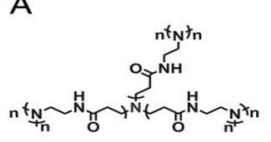

B

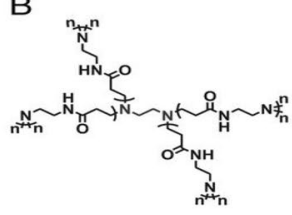
Divergent, $n=5 \quad(l=7)$

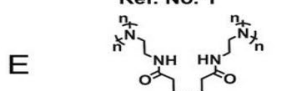

E

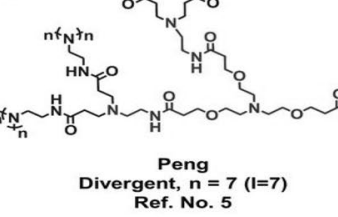

I

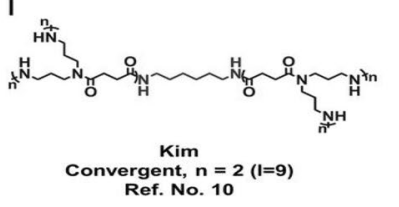
Tomalia
Ref., No. 1,2

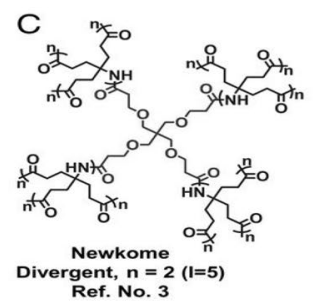

$\mathrm{F}$

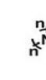

G

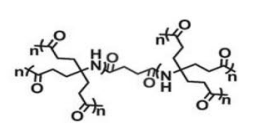

Weck

Convergent, $n=2(l=5)$
Ref. No. 7

$\mathrm{K}$

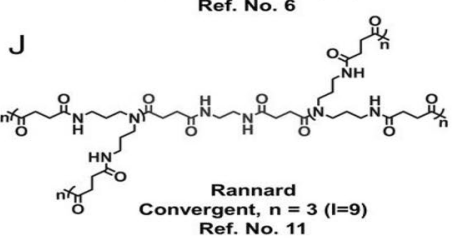

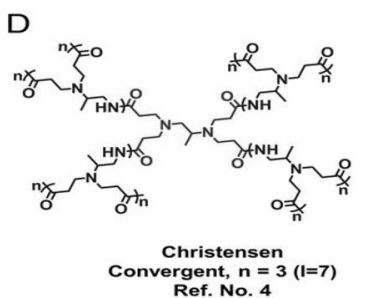

$\mathrm{H}$

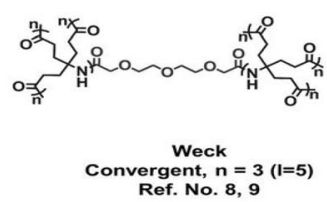

L

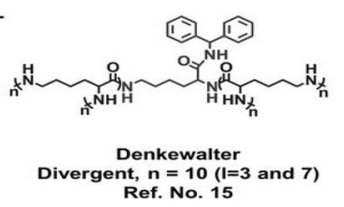

Fig. 8 Aliphatic polyamide and peptide dendrimers (a-l) cited in the literature [33 and references therein]

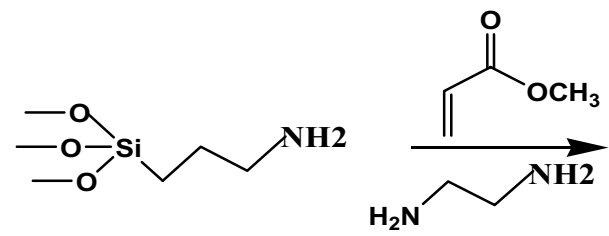

G1
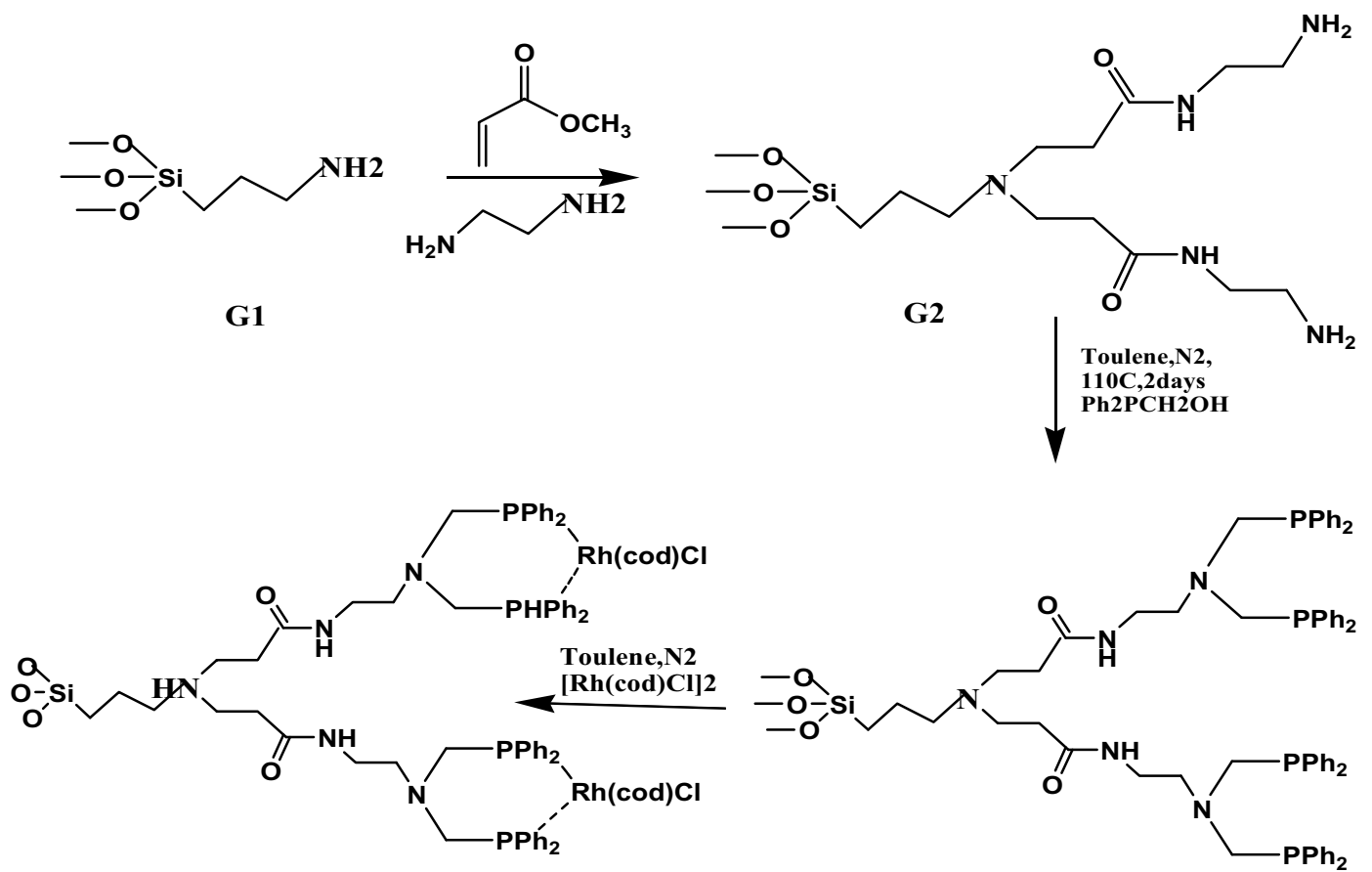

G1-C2

Fig. 9 Dendritic catalyst with greater reactivity and selectivity for hydroformylation reactions

Hawker [59], Inoue [60], Meijoral and Caminerd [25], Baars and Meijer [61], Moore [62], Berresheim et al. [63], Newkome [30], Schlüter and Rabe [64], Matthews et al. [65], Tomalia et al. [35], Vogtle et al. [36].
More than 60 families of dendrimers, each with unique properties and tailored for different types of application are described in literature. These applications are portrayed in Fig. 14. 


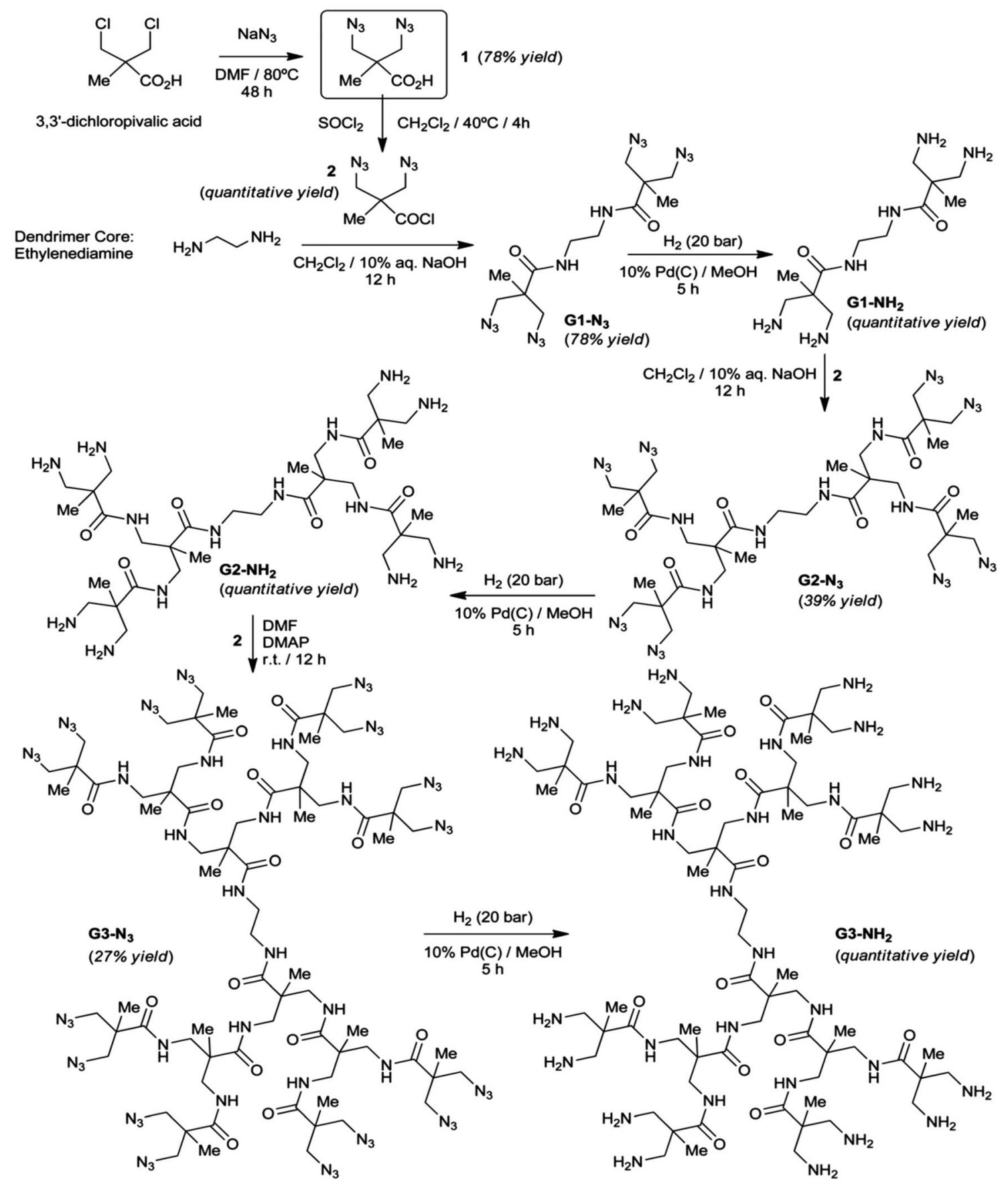

Fig. 10 Synthesis of dendrimer via successive acylation-hydrogenation reactions

\section{Dendrimers in biomedical field}

In recent era, the use of dendrimers in biomedical field has gain much curiosity from the researchers. Dendrimers are charming candidates for biomedical applications because of their special characteristics including: hyperbranching, size, shape i.e. globular structures, extending length/thickness, periphery functionalities, consistency, multivalency and high natural comparability. In particular, the threedimensional building of dendrimers can join an arrangement of naturally unique administrators to shape normally powerful conjugates. These dendrimers and related species can be easily functionalized and can behave as synthetic analogous of enzymes, proteins and viruses. Dendrimers and other molecules can either be connected to the outskirts or can be exemplified in their inside voids [66]. In modern 


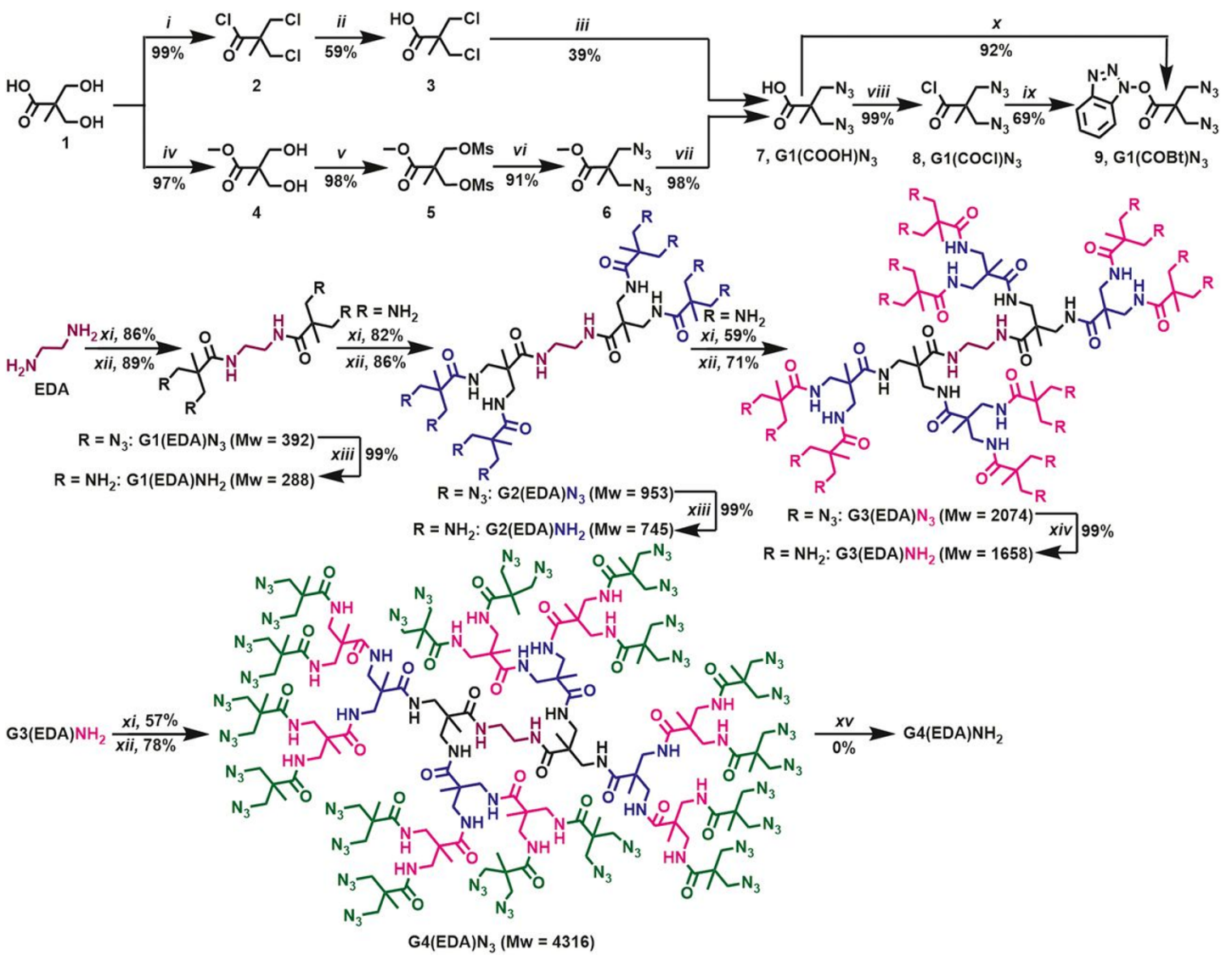

Reagents and conditions: (i) $\mathrm{SOCl}_{2}$, DMF, $23{ }^{\circ} \mathrm{C}, 18 \mathrm{~h}$, reflux, $24 \mathrm{~h}$ ); (ii) $\mathrm{H}_{2} \mathrm{O}, 7 \mathrm{M} \mathrm{NaOH}, 0{ }^{\circ} \mathrm{C}, 2 \mathrm{~h}$ ); (iii) $\mathrm{NaN}_{3}$, DMF: $\mathrm{H}_{2} \mathrm{O}(9: 1), 80{ }^{\circ} \mathrm{C}, 48 \mathrm{~h}$; (iv) $\mathrm{MeOH}$, Amberlyst-15, reflux, $5 \mathrm{~h}$; (v) $\mathrm{MsCl}, \mathrm{Et}_{3} \mathrm{~N}, \mathrm{CH}_{2} \mathrm{Cl}_{2}, 0-23{ }^{\circ} \mathrm{C}, 7 \mathrm{~h}$; (vi) $\mathrm{NaN}_{3}, \mathrm{DMF}, 90^{\circ} \mathrm{C}, 24 \mathrm{~h}$; (vii) $\mathrm{NaOH}, \mathrm{MeOH} / \mathrm{THF} / \mathrm{H}_{2} \mathrm{O}$ (eq-vol), $50{ }^{\circ} \mathrm{C}, 2 \mathrm{~h}$; (viii) $\mathrm{SOCl}_{2}, \mathrm{CH}_{2} \mathrm{Cl}_{2}, 3 \mathrm{~h}$, reflux; (ix) $\mathrm{HOBt}, \mathrm{Et}_{3} \mathrm{~N}, \mathrm{CH}_{2} \mathrm{Cl}_{2}, 0{ }^{\circ} \mathrm{C}, 0.5 \mathrm{~h}$, then $23{ }^{\circ} \mathrm{C}, 12 \mathrm{~h}$; (x) HOBt, DCC, DMAP, $\mathrm{CH}_{2} \mathrm{Cl}_{2}, 23{ }^{\circ} \mathrm{C}, 1 \mathrm{~h}$, then $35^{\circ} \mathrm{C}, 2 \mathrm{~h}$; (xi) $\mathrm{Gl}(\mathrm{COCl}) \mathrm{N}_{3}, \mathrm{Et}_{3} \mathrm{~N}, \mathrm{CH}_{2} \mathrm{Cl}_{2},-78{ }^{\circ} \mathrm{C}, 0.5 \mathrm{~h}$, then $23{ }^{\circ} \mathrm{C}, 12 \mathrm{~h}$; (xii) $\mathrm{G} 1(\mathrm{COBt}) \mathrm{N}_{3}, \mathrm{Et}_{3} \mathrm{~N}, \mathrm{CH}_{2} \mathrm{Cl}_{2}, 23{ }^{\circ} \mathrm{C}, 24 \mathrm{~h}$; (xiii) $10 \% \mathrm{Pd} / \mathrm{C}\left[10 \%\right.$ (wt/wt)], $\mathrm{H}_{2}$ (120 psi), $23{ }^{\circ} \mathrm{C}, 2 \mathrm{~h}$; (xiv) 10\% Pd/C [30\% (wt/wt)], $\mathrm{H}_{2}(120 \mathrm{psi}), 23{ }^{\circ} \mathrm{C}, 3 \mathrm{~h}$; (xv) $10 \% \mathrm{Pd} / \mathrm{C}\left[80 \%\right.$ (wt/wt)], $\mathrm{H}_{2}(120 \mathrm{psi}), 23{ }^{\circ} \mathrm{C}, 3 \mathrm{~h}$.

Fig. 11 Divergent synthesis of G4 of aliphatic polyamide dendrimers (PAMAM) with ethylenediamine core [33]

medicines, an assortment of such materials are being used, for instance, polyamidoamine (PAMAM) dendrimers can be utilized as potential blood substitutes [67]. The advancement of specific frameworks with exact sizes and shapes may lead to remedial applications like drug movement [68], quality transfection [69], and imaging [70-74].

Dendrimers in drug delivery One of the fundamental concerns of modern medicines is to enhance their pharmacokinetic properties especially for malignancy [75]. The drugs conjugate with polymeric species have been recognized by extended half-life, high stability, water solubility, reduced immunogenicity, and antigenicity [76]. The pathophysiological attributes of tumors incorporate broad angiogenesis bringing about hypervascularization, aberrant vascular architecture, enhanced permeability, and restricted lym- phatic drainage and consequently cause the particular gathering of macromolecules in tumor tissue. This phenomenon is known as 'enhanced permeation and retention' [77]. The dendrimer conjugates indicate high solubility, decreased systemic lethality and particular collection in solid tumors. The structures and tunable surface functionalities of dendrimers allow for the encapsulation/complexation/conjugation of multiple entities, i.e. the drug molecules, and genetic materials, targeting agents and dyes, either in the core or on the surface, rendering them ideal carriers for various drugs.

Initial investigations on dendrimers as potential drug delivery carrier were focused on their use as unimolecular micelles and 'dendritic boxes' for encapsulation of drug molecules. In initial studies, DNA was complexed with PAMAM dendrimers for gene delivery applications [78], and hydrophobic drugs and dye were incorporated into various 


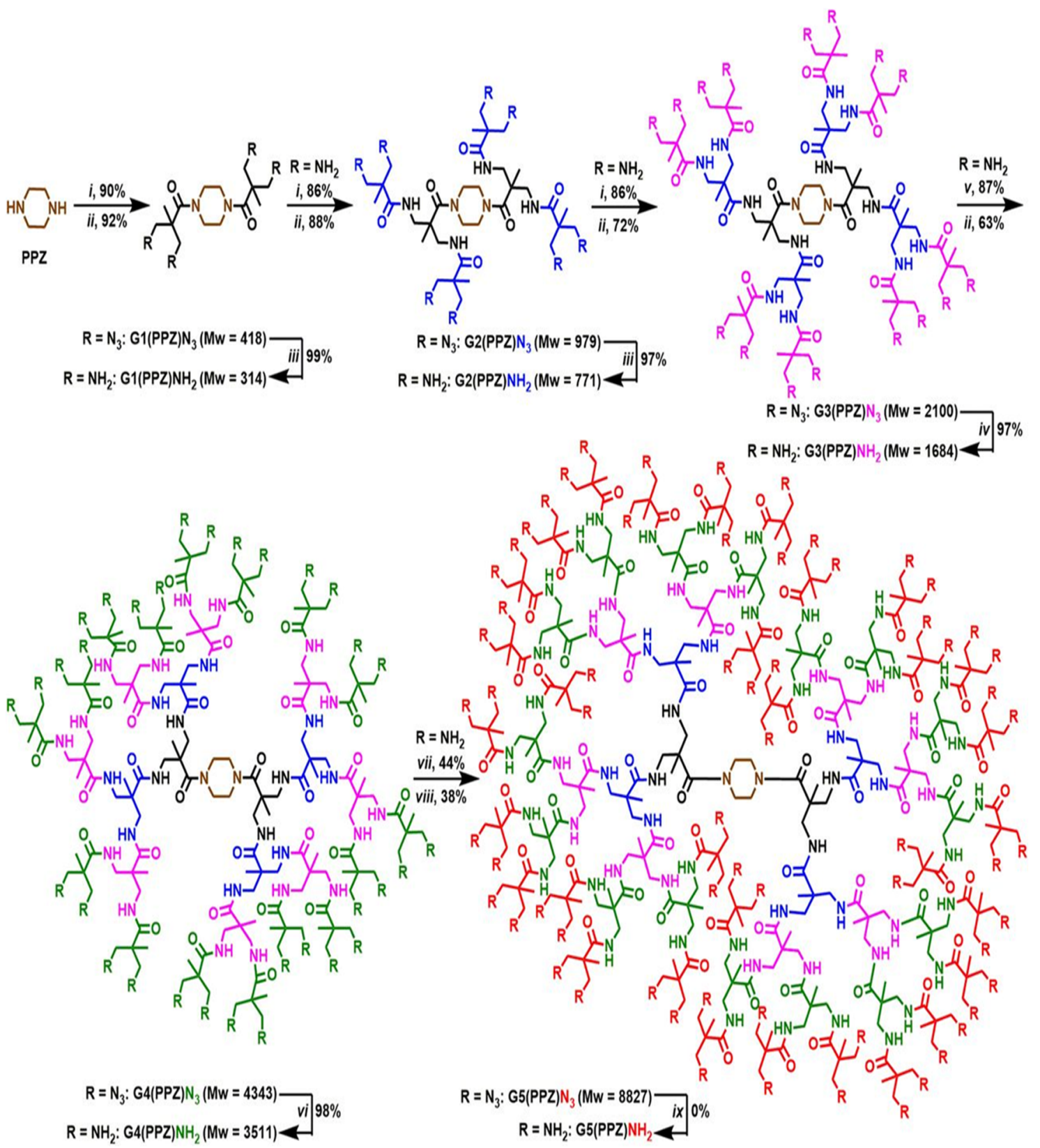

Reagents and conditions: (i) $\mathrm{G} 1(\mathrm{COBt}) \mathrm{N}_{3}, \mathrm{Et}_{3} \mathrm{~N}, \mathrm{CH}_{2} \mathrm{Cl}_{2}, 23{ }^{\circ} \mathrm{C}, 24 \mathrm{~h}$; (ii) $\mathrm{G} 1(\mathrm{COCl}) \mathrm{N}_{3}, \mathrm{Et}_{3} \mathrm{~N}, \mathrm{CH}_{2} \mathrm{Cl}_{2},-78{ }^{\circ} \mathrm{C}, 0.5$ h, then $23{ }^{\circ} \mathrm{C}, 12 \mathrm{~h}$; (iii) $10 \% \mathrm{Pd} / \mathrm{C}$ [15\% (wt/wt)], $\mathrm{H}_{2}(120 \mathrm{psi}), 23{ }^{\circ} \mathrm{C}, 3 \mathrm{~h}$; (iv) $10 \% \mathrm{Pd} / \mathrm{C}$ [20\% (wt/wt)], $\mathrm{H}_{2}(120$ psi), $23{ }^{\circ} \mathrm{C}, 3 \mathrm{~h}$; (v) Gl(COBt) $\mathrm{N}_{3}, \mathrm{Et}_{3} \mathrm{~N}, \mathrm{CH}_{2} \mathrm{Cl}_{2}, 23{ }^{\circ} \mathrm{C}, 48 \mathrm{~h}$; (vi) $10 \% \mathrm{Pd} / \mathrm{C}\left[50 \%\right.$ (wt/wt)], $\mathrm{H}_{2}(120 \mathrm{psi}), 23{ }^{\circ} \mathrm{C}, 8 \mathrm{~h}$; (vii) $\mathrm{Gl}(\mathrm{COBt}) \mathrm{N}_{3}, \mathrm{Et}_{3} \mathrm{~N}, \mathrm{CH}_{2} \mathrm{Cl}_{2}, 23{ }^{\circ} \mathrm{C}, 72 \mathrm{~h}$; (viii) $\mathrm{Gl}(\mathrm{COCl}) \mathrm{N}_{3}, \mathrm{Et}_{3} \mathrm{~N}, \mathrm{CH}_{2} \mathrm{Cl}_{2},-78^{\circ} \mathrm{C}, 1 \mathrm{~h}$, then $23{ }^{\circ} \mathrm{C}, 24 \mathrm{~h}$; (ix) $10 \% \mathrm{Pd} / \mathrm{C}[80 \%(\mathrm{wt} / \mathrm{wt})], \mathrm{H}_{2}(120 \mathrm{psi}), 23{ }^{\circ} \mathrm{C}, 8 \mathrm{~h}$.

Fig. 12 Divergent synthesis of G5 aliphatic polyamide dendrimers (PAMAM) with piperazine (PPZ) core [33]

dendrimer cores $[20,24,78-80]$. An advantage of using dendritic unimolecular micelles is their structure maintenance at all concentrations due to covalently connected hydrophobic segments. However, the release of drug molecules from the dendrimer core is difficult to control. In some cases, harsh conditions are needed, whereas in others, the encapsulation is not much effective and the drug molecules are released relatively rapidly [81, 82].

Another approach to develop dendrimers as drug carriers is to exploit their multivalency for the covalent attachment of drug molecules to the dendrimer periphery. The drug loading and releasing can be controlled by varying the dendrimer 


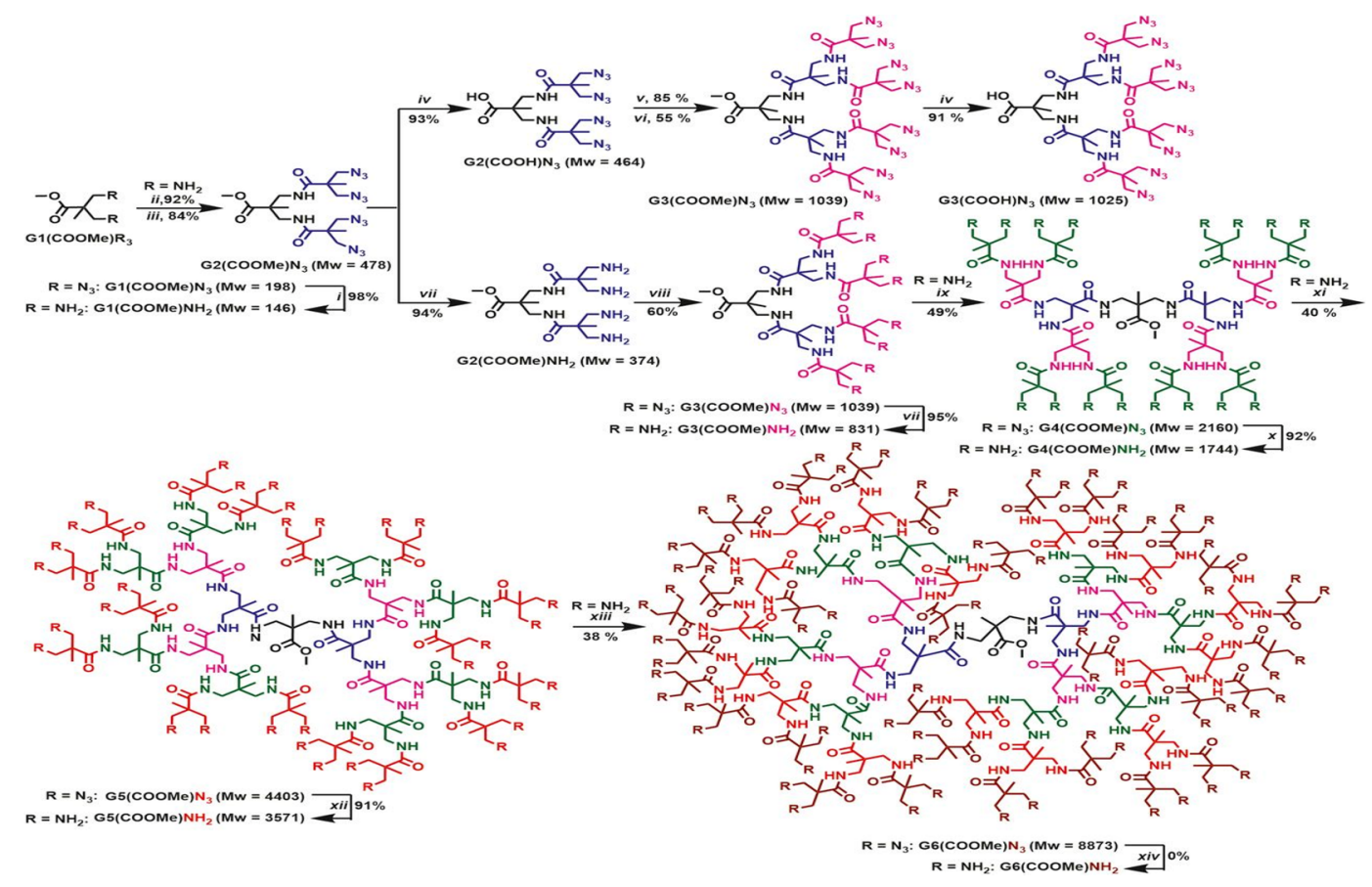

Reagents and conditions: (i) $10 \% \mathrm{Pd} / \mathrm{C}\left[10 \%\right.$ (wt/wt)], $\mathrm{H}_{2}(120 \mathrm{psi}), \mathrm{MeOH}, 23{ }^{\circ} \mathrm{C}, 3 \mathrm{~h}$; (ii) $\mathrm{G} 1(\mathrm{COBt}) \mathrm{N}_{3}, \mathrm{Et}_{3} \mathrm{~N}$, $\mathrm{CH}_{2} \mathrm{Cl}_{2}, 23{ }^{\circ} \mathrm{C}, 24 \mathrm{~h}$; (iii) $\mathrm{G} 1(\mathrm{COCl}) \mathrm{N}_{3}, \mathrm{Et}_{3} \mathrm{~N}, \mathrm{CH}_{2} \mathrm{Cl}_{2},-78^{\circ} \mathrm{C}, 0.5 \mathrm{~h}$, then $23{ }^{\circ} \mathrm{C}, 12 \mathrm{~h}$; (iv) $\mathrm{NaOH}, \mathrm{THF} / \mathrm{MeOH} / \mathrm{H}_{2} \mathrm{O}$ [1/1/1 (vol/vol/vol)], $50{ }^{\circ} \mathrm{C}, 2 \mathrm{~h}$; (v) DCC, HOBt, $\mathrm{CH}_{2} \mathrm{Cl}_{2}, 23{ }^{\circ} \mathrm{C}, 6 \mathrm{~h}$, then $35^{\circ} \mathrm{C}, 2 \mathrm{~h}$, then G1(COOMe) $\mathrm{NH}_{2}, \mathrm{Et}_{3} \mathrm{~N}$, $\mathrm{CH}_{2} \mathrm{Cl}_{2}, 23{ }^{\circ} \mathrm{C}, 24 \mathrm{~h}$; (vi) $\mathrm{SOCl}_{2}, \mathrm{CH}_{2} \mathrm{Cl}_{2}$, reflux, $4 \mathrm{~h}$, then $\mathrm{G} 1(\mathrm{COOMe}) \mathrm{NH}_{2}, \mathrm{Et}_{3} \mathrm{~N}, \mathrm{CH}_{2} \mathrm{Cl}_{2},-78{ }^{\circ} \mathrm{C}, 0.5 \mathrm{~h}$, then 23 ${ }^{\circ} \mathrm{C}, 15 \mathrm{~h}$; (vii) $10 \% \mathrm{Pd} / \mathrm{C}\left[10 \%\right.$ (wt/wt)], $\mathrm{H}_{2}$ (120 psi), $\mathrm{MeOH}, 23{ }^{\circ} \mathrm{C}, 2 \mathrm{~h}$; (viii) $\mathrm{G} 1(\mathrm{COBt}) \mathrm{N}_{3}, \mathrm{Et}_{3} \mathrm{~N}, \mathrm{CH}_{2} \mathrm{Cl}_{2}, 23{ }^{\circ} \mathrm{C}$, $24 \mathrm{~h}$; (ix) G1(COBt)N $3, \mathrm{Et}_{3} \mathrm{~N}, \mathrm{CH}_{2} \mathrm{Cl}_{2}, 23{ }^{\circ} \mathrm{C}, 48 \mathrm{~h}$; (x) 10\% Pd/C [20\% (wt/wt)], $\mathrm{H}_{2}$ (120 psi), $\mathrm{MeOH}, 23{ }^{\circ} \mathrm{C}, 2 \mathrm{~h}$; (xi) $\mathrm{Gl}(\mathrm{COBt}) \mathrm{N}_{3}, \mathrm{Et}_{3} \mathrm{~N}, \mathrm{CH}_{2} \mathrm{Cl}_{2}, 23^{\circ} \mathrm{C}, 48 \mathrm{~h}$; (xii) 10\% Pd/C [30\% (wt/wt)], $\mathrm{H}_{2}$ (120 psi), $\mathrm{MeOH}, 23{ }^{\circ} \mathrm{C}, 2 \mathrm{~h}$; (xiii) $\mathrm{G} 1(\mathrm{COBt}) \mathrm{N}_{3}, \mathrm{Et}_{3} \mathrm{~N}, \mathrm{CH}_{2} \mathrm{Cl}_{2}, 23{ }^{\circ} \mathrm{C}, 48 \mathrm{~h}$; (xiv) $10 \% \mathrm{Pd} / \mathrm{C}\left[80 \%\right.$ (wt/wt)], $\mathrm{H}_{2}(120 \mathrm{psi}), \mathrm{MeOH}, 23{ }^{\circ} \mathrm{C}, 2 \mathrm{~h}$.

Fig. 13 The convergent synthesis of three generations, and the divergent synthesis of six generations of aliphatic polyamide dendrons [33]

generation number and by incorporating degradable linkages between the drug and dendrimer. For example, embodiment of the anticancer medicine cisplatin inside PAMAM dendrimers gave conjugates that demonstrated more moderate release, lower lethality, increased water solubility and selective accumulation in solid tumors as compare to free cisplatin [83]. Furthermore, the dendrimer-platinum complex has been found to show increased efficacy relative to cisplatin in the treatment of subcutaneous B16F10 melanoma. In such a way, Malik et al. [84] have developed an anticancer prodrug 'complexed carboxylate-finished PAMAM dendrimer with cisplatin' that can release cisplatin particles by hydrolysis. Malik and Duncan [85] have claimed that the dendritic polymer palatinate can be administered in required amounts intravenously, orally, parentally, subcutaneously or topically to an animal having a malignant tumor. The dendritic polymer palatinates have been claimed to show high drug efficiency, high drug carrying capacity, good water solubility, good stability on storage, reduced toxicity, and improved anti-tumor activity in vivo. In a similar fashion, Balogh et al. [86] have incorporated silver salts inside PAMAM dendrimers that demonstrated moderate silver release rates with enhanced antimicrobial activity against Staphylococcus aureus, Pseudomonas aeruginosa and Escherichia coli microorganisms.

PAMAM dendrimers as carrier have been widely studied for oral drug delivery [87-99] because of their water solubility, unique branching architecture and compacts spherical shape in solution [100]. The large number of arms and peripheral amine groups can be utilized to immobilize drugs, enzymes, antibodies, or other bioactive agents [101, 102].

Dendrimers also have many applications in trans dermal drug delivery of bioactive drugs possessing hydrophobic moieties in their structures and have low water solubilities [103].

Gene delivery Genetic treatments have a significant role in our armamentarium. A specific and proficient delivery sys- 
Fig. 14 Applications of dendrimers

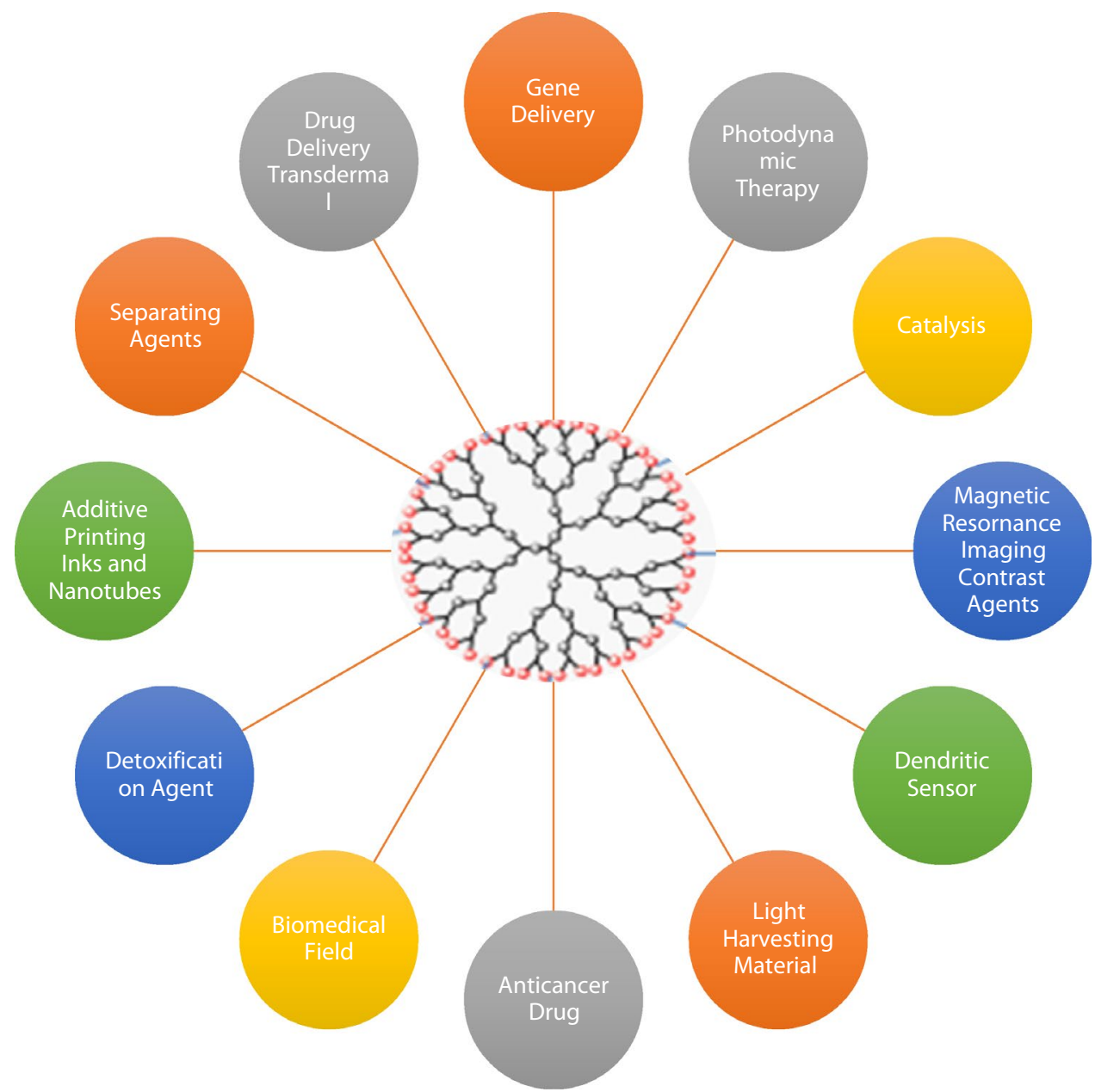

tem is very important for genetic therapies [104]. Dendrimers are being investigated to be used to introduce genes into cells without harmful effect on the DNA. Polyamidoamine (PAMAM) dendrimer-DNA complexes encapsulated in biodegradable polymer have been investigated for substrateinterceded gene delivery. Fast-degrading functional polymer has been claimed to have unbelievable potential for limited transfection $[105,106]$.

\section{Dendrimers as magnetic resonance imaging (MRI) contrast} agents Magnetic resonance imaging (MRI) is used to provide high-quality three-dimensional images of organs and tissues in the body. The signal intensity in MRI mainly stems from the relaxation rate of water protons (in vivo) and can be enhanced by using a contrast agents i.e. gadolinium chelates, super paramagnetic iron oxide particles etc., prior to the scan. The important properties of MRI contrast agents include good biocompatibility, low toxicity, and high relaxivity. The low molecular weight MRI contrast agents can diffuse rapidly from blood vessels into the interstitial space and can excrete from the body very rapidly [107]. Paramagnetic metal chelates such as
Gd(III)- $N, N^{\prime}, N^{\prime \prime}, N^{\prime \prime \prime}$-tetracarboxymethyl-1,4,7,10-tetraaz acyclododecane (Gd(III)-DOTA), Gd(III)-diethylenetriaminepentaacetic acid (Gd(III)-DTPA) and their derivatives have been reported to be used as contrast agents for MRI. These metal chelates increased the relaxation rate of surrounding water protons [108]. Short circulation times within the body and inefficient discrimination between normal and diseased tissues were the major problems. Subsequently, macromolecular Gd(III) complexes were developed by conjugating Gd(III) chelates to biomedical polymers, i.e. polysaccharides, proteins, and poly(amino acids) to improve image quality. These macromolecular agents demonstrated much better contrast enhancement for cancer imaging and blood pool imaging in animal models. Unfortunately, their clinical application faced limitations due their slow excretion rate and more accumulation within liver which enhances the risk of potential toxicity by Gd(III) ions released during the metabolic processes of these agents [109, 110]. Wiener et al. [111] have developed a new class of MRI contrast agents, Gd(III) DTPA-based PAMAM dendrimers, with much more proton relaxation enhancements and molecular relaxivities. 
The G6 PAMAM dendrimer possessing 192 reactive terminal amines, has been conjugated to 2-(4-isothiocyanatobenzyl)-6-methyl-(DTPA) through a thiourea linkage. This dendrimeric contrast agent has been claimed to have relaxivity up to six times higher than that of free Gd(III)DTPA complex. In vivo studies on rabbits have illustrated the excellent MRI images of blood vessels and long blood circulation times (>100 min). Kobayashi et al. [112] have investigated the relationship between relaxivity and dendrimer generations using Gd(III)-DTPA-PAMAM contrast agents. The study revealed that relaxivity increased as the dendrimer generation increased, but beyond 7th generation, the increase was insignificant.

Dendrimers in tissue engineering The tissue engineering has developed in the last few decades [113-115]. The regeneration of native tissues by supplementing the natural healing process and the creation of entire organs for transplantation have been main focus. The first is the selection of an appropriate scaffold material upon which cell/tissue can grow [116]. The scaffold may have porous structure that allow the diffusion of nutrients to and waste products away from the cells. It must be biodegradable at such a rate that after regeneration of native extra cellular matrix (ECM), it eventually replaced altogether. Polymeric scaffold compositions can be divided into two main categories: natural and synthetic. Natural scaffolds have been constructed from proteins, carbohydrates, or glycoproteins [117-124]. The synthetic linear polymers, such as poly(lactic acid) (PLA), poly(glycolic acid) (PGA), poly(caprolactone) (PCL), and poly(ethylene glycol) (PEG) have also been used extensively as scaffold materials $[125,126]$. The dendrimers have also been utilized either as auxiliaries to an existing scaffold, or as primary scaffold components in tissue engineering. There are many examples where dendritic species including PAMAM dendrimers have been incorporated into scaffolds for the regeneration of a variety of tissues and cell types [127].

Chan et al. [128] incorporated G1 PAMAM dendrimer into extracellular matrix (CEM) derived from the perimuscular subserosal connective tissue of porcine cholecysts developed in their laboratory [129] in varied feed concentrations of the dendrimer in CEM using the EDC/NHS cross-linking system which resulted in covalent binding of PAMAM on CEM. They observed varied degrees of cross-linking, better stability of CEM to enzymatic degradation, increase in amine functionalities useful for tethering bioactive agents, upholding of tensile strength with enhanced flexibility of scaffold, and maintenance of the ability of CEM to support cells in vitro. On the other hand, Boduch-Lee et al. [130] have designed and synthesized star polycaprolactone (PCL)hydroxyapatite films for use as a biodegradable matrix for bone tissue engineering. They used a scaffold composed of
PCL chains conjugated to a poly(lysine) dendritic core to fabricate an HA composite for in vitro bone regeneration. The cell line MG-63 was used to evaluate the effect of these scaffolds. They observed that the performance of dendrimerPCL HA hybrid was much better than linear PCL both in bone cell growth and adhesion over $24 \mathrm{~h}$.

Dendrimers in vaccine development Vaccination has been an influential tool to control infectious diseases produced by microbial pathogens i.e. bacteria, virus, etc. With the passage of time, the pathogens become resistant to the existing vaccines as well as mutations in the pathogens lead to more harmful varieties. Therefore, there is always a growing need for new generations of vaccines with optimal qualities to target these infectious diseases [131]. Dendrimers, due to their optimum physical characteristics, have ability to act as efficient immune stimulating compounds (adjuvants) that can enhance the efficacy of vaccines. In addition, dendrimers can provide well-defined multivalent scaffolds to produce conjugates with immune stimulators and/or antigens [132]. These conjugates supposed to be superlative exporters of small antigens upon administration without any side effect. In this respect, peptide dendrons build up solely from lysine have gain much interest from the researchers [47, 133]. The two amino groups ( $\mathrm{R}$ and $\varepsilon$ ) present in lysine molecule can act as branching points for logarithmic development. Thus, two-layer and three-layer dendrons may have four and eight free amino groups, respectively. Tam coined the term "multiple antigenic peptide" (MAP) for such a structure.

Wang et al. [134] have examined the vaccine function of a MAP which was obtained by coupling the V3 loop (third variable region of envelope glycoprotein gp120 of HIV) sequence to lysine dendrimer by Tam and his fellows $[21,135]$. Elicitation of relatively high and sustained levels of HIV-1-specific neutralizing antibodies in animals was observed. Baigude et al. [136] have reported the synthesis of first glycopeptide dendrimer-type AIDS vaccine model consisting of a V3 loop peptide-succinyl-maltose-proline-poly(lysine) dendrimer scaffold. This vaccine model has been claimed to have enhanced water solubility, low cell toxicity, and antigenicity of dendrimer itself due to the presence of sugar moieties [64]. Up till now, several studies have been performed using dendrimeric species especially PAMAM dendrimers as adjuvants against various pathogens. Enhanced efficacy and reduction in adverse effect on host demonstrate that dendrimers in conjugation with vaccines/antigens can be used successfully [137-143].

Photodynamic therapy (PDT) Photodynamic therapy (PDT) is a therapeutic method for treating various oncological and related diseases. First, a photosensitizer (PS) is accumulated in specific target cells. Then, selective optical irradiation (visible or near IR) of an appropriate wavelength is used 
to generate highly reactive singlet oxygen species (ROS) which induce apoptosis and/or necrosis culminating in cellular death. The continuing efforts to improve PDT focus on strategies to enhance the solubility of the PS, design new PS molecules, and strategies for higher accumulation of PS in the targeted tissue. In PDT, PS-dendrimer conjugates have been tested by three strategies: entrapment of PS in the voids of a dendrimer [144], covalent linkage between PS and dendrimer [145], and generation of dendrimer using PS as a scaffold [146]. The PS-dendrimers have been claimed to show significant tumor suppression as compared to free PS in a xenograft animal tumor model. It has been reported that conjugation of a PS with dendrimers especially PAMAMs, and targeting agent has enhanced the photodynamic therapeutic effects of the PS [147, 148].

\section{Dendritic sensors}

A single molecule of a dendrimer contains large number of terminal functional groups to be useful for covalent association or closeness of a high number of species. Balzani et al. have studied the fluorescence of a G4 poly(propylene amine) dendrimer elaborated with thirty two dansyl units at the periphery [144]. The amine units allow the rational number of a metal ions to coordinate. It was observed that the strong fluorescence decreased by the incorporation of $\mathrm{Co}^{2+}$ inside the dendrimer. It has been claimed that low concentrations of $\mathrm{Co}^{2+}$ ions $\left(4.6 \times 10^{-7} \mathrm{M}\right)$ can be identified using dendrimer concentration of $4.6 \times 10^{-6} \mathrm{M}$. So the dendrimers containing fluorescent could be use full as a sensors [145].

\section{Effect of $\mathrm{pH}$ change on dendrimers}

The effect of $\mathrm{pH}$ on different generations of PAMAM dendrimers has been investigated (Fig. 15). The PAMAM dendrimers $\left(\mathrm{G}_{1}-\mathrm{G}_{7}\right)$ were explored in acidic, neutral, and basic $\mathrm{pH}$ atmospheres. The change in $\mathrm{pH}$ effected the shapes of the dendrimers. The dendrimers usually attained more compact globular shapes at higher $\mathrm{pH}$ with more prominent effect in the higher generations $\left(\mathrm{G}_{5}-\mathrm{G}_{7}\right)$ at basic $\mathrm{pH}$ [149].

\section{Dendrimers used as catalysts}

The role of dendritic polymeric species in catalysis have been investigated by many research groups. The high surface area and high solubility in reaction media are among the prominent features of the dendrimers which make them useful as nanoscale catalysts. Dendrimers have multifunctional surfaces and the catalytic sites are usually exposed. The bigger dendrimer-based catalysts may have many terminal active sites. These catalysts can be separated efficiently by filtration [150]. Dendrimers have capacity to encapsulate a single catalytic site, i.e. metallic or non metallic whose activities can be enhanced by dendritic superstructure [151]. Insoluble materials, for e.g. metals, can be entrapped in the dendrimers and can transported into the reaction media.

There are numerous examples of using dendrimers in organometallics $[152,153]$ such as ferricenic sandwich [154, 155] with remarkable redox catalysis properties. Since 1994, a lot of work has been developed in the area of catalysis by entrapping the catalyst in the periphery, the scaffolding, or on the core of dendrimers [14, 48, 156-173]. The main goal always remain to find the ideal catalyst with high catalytic efficiency, selectivity for whatever reaction, versatile (substrate, metal, conditions), easily recoverable/recyclable and longevity (durable and stable). The use of PAMAM dendrimeric species always remain a point of interest by the researchers in catalysis. One example is the use of PAMAM dendrons based on silica-coated magnetic nanoparticles for hydroformylation reaction with very high reactivity and selectivity [45].

\section{Dendrimers used as light harvesting material}

The designing of molecules with controlled motion of charges is always remain the main focus for the development of light harvesting materials. The multiple functionality and structural features including in the functional groups moving from the periphery to the core render dendrimers to be used in light harvesting (Fig. 16). Most of the studies validate the energy funneling from the chromophore at the periphery to a chromophore at the core [174]. A $\sigma$-conjugated dendrimeric family based on truxene and thienylethylene has been asserted to exhibit intrinsic energy gradient from periphery to the core. A broad absorption in the UV-Vis range and a proficient energy transfer to the lower energy centre has also been claimed. Such type of dendrimeric conjugates may have remarkable potential as light harvesting materials [175].

\section{Dendrimers used as paints, additives and printing inks}

Dendrimers are being used in toners composition as additives. Xerox Corporation has incorporated dendrimeric additives in the form of charge enhancing species [176]. Dendrimeric additives ensure uniform adhesion of ink to both polar and non-polar foils. The multifunctionality of a dendrimer facilitate the fixation of pigment constituents and exterior of the foils (Fig. 17). Dendritic polymers are being used as a part of polyurethane paints which offer superficial hardness, light swiftness and weathering resistance in addition to polish. These characteristics have encourage their use in furniture and car ventures. Use of dendrimeric auxiliaries may alter the peripheral portrayal of thermoplastic resin with synergic effects on stiffness, strength, process ability and high softening temperature. 
Fig. 15 PAMAM dendrimers generations $\left(\mathrm{G}_{1}-\mathrm{G}_{7}\right)$ at low, neutral, and high $\mathrm{pH}$

\section{Low pH}
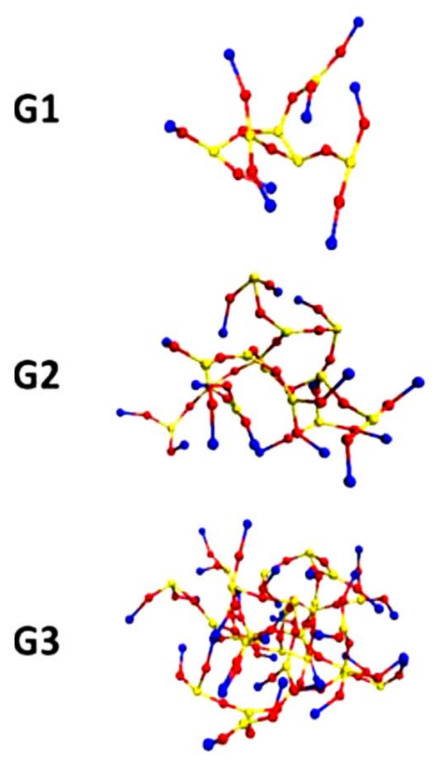

G4

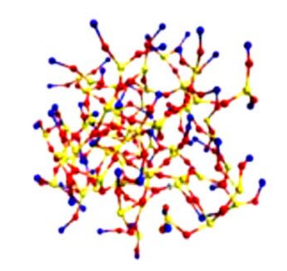

G5

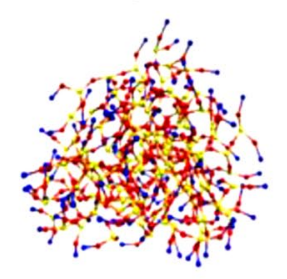

G6

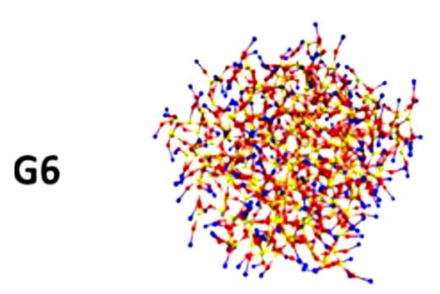

\section{G7}

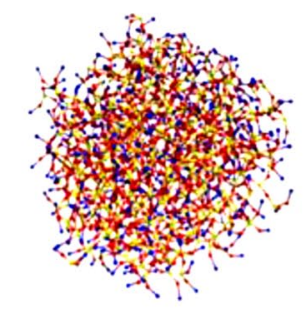

Neutral pH
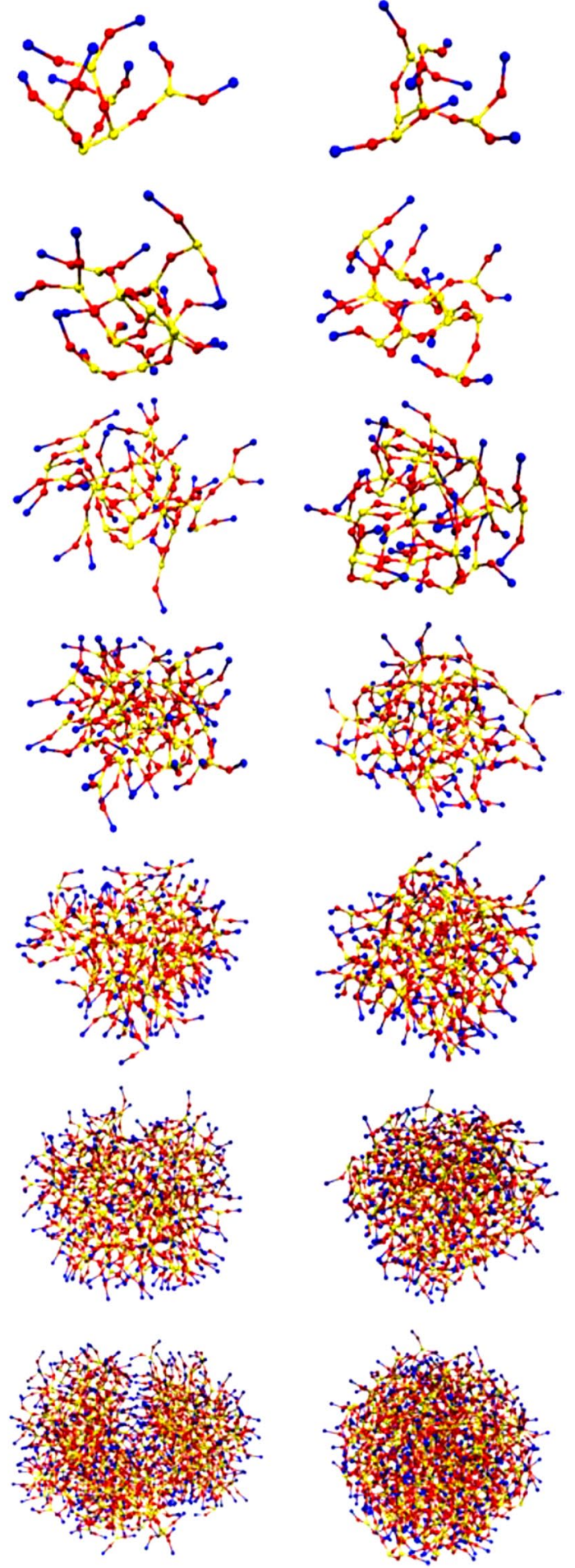

\section{Dendrimers used as a separating agent}

The dendrimeric species have also been investigated as separating agents. The ease to form micelle structure provide high functional density at the surface, high surface area and ease of separation for isolation and regeneration of the compound. It has been reported that unmodified commercial dendrimers containing amine and hydroxyl functionalities 


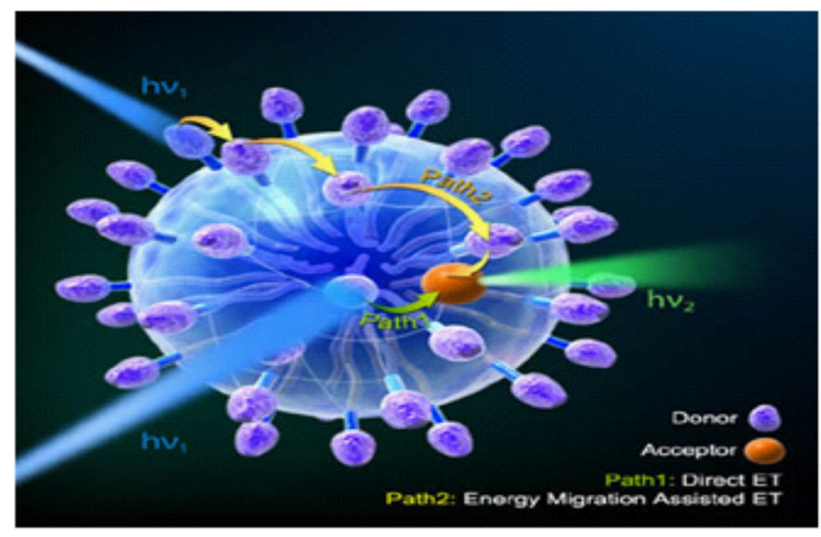

Fig. 16 Dendrimer used as light harvesting material

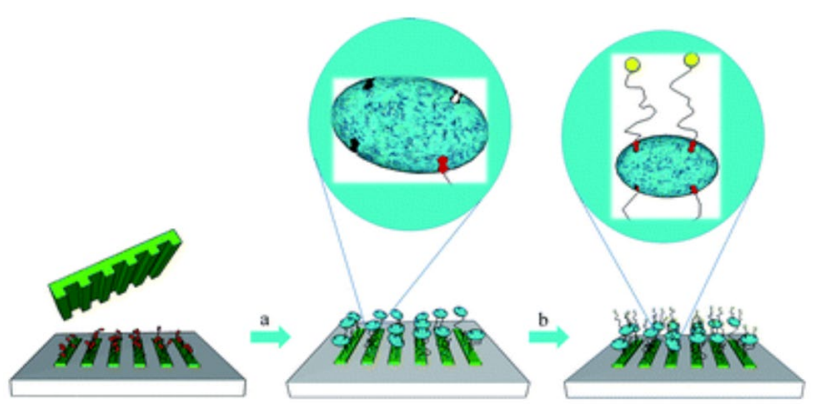

Fig. 17 Dendrimers used as printing inks, additive, and paints

are generally more effective for boron absorption and could be used for the removal boron like species from sea water. Certain polyamidoamine (PAMAM) dendrimers have been reported to be used as chelating agents for the removal of certain metal ions from waste water and as well as from contaminated soil $[177,178]$. Some other modified chelating PAMAM and poly(propylene imine) dendrimer have also been claimed to be functional for the removal of hard metal cations $[179,180]$, polycyclic aromatic hydrocarbons [181] and other particles [182].

\section{Dendrimers in electronic devices}

The good solubility and easiness to prepare a homogeneous film are absolutely necessary for a material to be used in organic electronic devices (e.g., integrated circuits, FETs, thin-film transistors, solar cells, field quenching devices, light-emitting transistors, light-emitting electrochemical cells, optical detectors, organic photoreceptors, organic laser diodes, and organic electroluminescent devices). Dendrimers incorporating a specify component can serve as holeinjecting, hole-transporting, electron transporting, or holeblocking materials $[183,184]$. Majoral's group has designed dedrimers incorporated with fluorophores at the periphery which can absorb two photons and can be utilized as fluorescent markers for biomedical applications [185].

\section{Dendrimers for remediation of environmental problems}

Dendrimers architecture i.e. high density of functionalities at periphery and interior voids is suitable for entrapping small gas molecules and low molecular weight organic compounds as well as metal cations. This property enables the dendrimers to be used in the field of environmental remediation environmental [186-189]. PAMAM dendrimers with amine, carboxyl, and hydroxyl terminal groups have been used to remove the toxic metal ions from waste water and contaminated soil [177-180]. Some ultrafiltration membranes supported with dendrimeric architecture have also been designed with potential application in soft water.

\section{Conclusion}

In this review, we emphasized on some key aspect of dendrimers such as synthesis, characterization and their applications.

\section{References}

1. D.A. Tomalia, A.M. Naylor, W.A. Goddard III, Angew. Chem. Int. Ed. Engl. 29, 138-175 (1990)

2. G.R. Newkome, Z.Q. Yao, G.R. Baker, V.K. Gupta, J. Org. Chem. 50(11), 2003-2004 (1985)

3. D.A. Tomalia, H.D. Durst, Topic in current chemistry, in Supramolecular Chemistry I, ed. by E.W. Weber (Springer, Berlin, 1993), pp. 193-313165

4. D.A. Tomalia, Prog. Polym. Sci. 30, 294-324 (2005)

5. D.A. Tomalia, H. Baker, J. Dewald, M. Hall, G. Kallos, S. Martin, J. Roeck, J. Ryder, P. Smith, Polym. J. 17, 117-132 (1985)

6. D.A. Tomalia, J.B. Christensen, U. Boas, Dendrimers, Dendrons, and Dendritic Polymers: Discovery, Applications, and the Future (Cambridge University Press, Cambridge, 2012)

7. D. Wang, D. Astruc, Coord. Chem. Rev. 257, 2317-2334 (2013)

8. M.A. Mintzer, M.W. Grinstaff, Chem. Soc. Rev. 40, 173-190 (2011)

9. R.K. Tekade, P.V. Kumar, N.K. Jain, Chem. Rev. 109, 49-87 (2009)

10. S.H. Medina, M.E. El-Sayed, Chem. Rev. 109, 3141-3157 (2009)

11. C. Dufès, I.F. Uchegbu, A.G. Schätzlein, Adv. Drug Deliv. Rev. 57, 2177-2202 (2005)

12. O. Rolland, C.-O. Turrin, A.-M. Caminade, J.-P. Majoral, New J. Chem. 33, 1809-1824 (2009)

13. D. Astruc, E. Boisselier, C. Ornelas, Chem. Rev. 110, 1857-1959 (2010)

14. J.N.H. Reek, S. Arévalo, R. van Heerbeek, P.C.J. Kamer, P.W.N.M. van Leeuwen, Advances in Catalysis (Academic Press, New York, 2006), pp. 71-15149

15. B.M. Rosen, C.J. Wilson, D.A. Wilson, M. Peterca, M.R. Imam, V. Percec, Chem. Rev. 109, 6275-6540 (2009) 
16. T. Emrick, J.M.J. Fréchet, Curr. Opin. Colloid Interface Sci. 4, 15-23 (1999)

17. D.A. Tomalia, D.M. Hedstrand, M.S. Ferritto, Macromolecules 24, 1435-1438 (1991)

18. C.J. Hawker, J.M.J. Fréchet, J. Chem. Soc. Chem. Commun. 112, 1010-1013 (1990)

19. C.J. Hawker, J.M.J. Fréchet, J. Am. Chem. Soc. 112, 7638-7647 (1990)

20. C.J. Hawker, K.L. Wooley, J.M.J. Fréchet, J. Chem. Soc. Perkin. Trans. 1, 1287-1297 (1993)

21. J.P. Tam, Proc. Natl. Acad. Sci. USA 85, 5409-5413 (1988)

22. E. Buhleier, W. Wehner, F. Vögtle, Synthesis 2, 155-158 (1978)

23. D. A. Tomalia, J. R. Dewald, M. R. Hall, S. J. Martin, P. B. Smith, Preprints, 1st SPSJ Polym. Conf., Soc. Polym. Sci. Jpn. Kyoto, p. 65 (1984)

24. G.R. Newkome, C.N. Moorefield, G.R. Baker, M.J. Saunders, S.H. Grossman, Angew. Chem. Int. Ed. Eng. 30, 1178-1180 (1991)

25. J.-P. Majoral, A.-M. Caminade, Chem. Rev. 99, 845-856 (1999)

26. W.B. Turnbull, J.F. Stoddart, Rev. Mol. Biotechnol. 90, 231-255 (2002)

27. R.H.E. Hudson, M.J. Damha, J. Am. Chem. Soc. 115, 2119-2124 (1993)

28. R.H.E. Hudson, S. Robidoux, M.J. Damha, Tetrahedron Lett. 39, 1299-1302 (1998)

29. T.W. Nilsen, J. Grazel, W. Prensky, J. Theor. Biol. 187, 273-284 (1997)

30. G.R. Newkome, E. He, C. Moorefield, Chem. Rev. 99, 16891746 (1999)

31. J.M.J. Fréchet, D.A. Tomalia, Dendrimers and Other Dendritic Polymers (Wiley, Chichester, 2001)

32. M. Pittelkow, J.B. Christensen, Org. Lett. 7, 1295-1298 (2005)

33. D. Jishkariani, C.M. MacDermaid, Y.N. Timsina, S. Grama, S.S. Gillani, M. Divar, S.S. Yadavalli, R.O. Moussodia, P. Leowanawat, A.M.B. Camacho, R. Walter, M. Goulian, M.L. Klein, V. Percec, Proc. Natl. Acad. Sci. USA 114, 2275-2284 (2017)

34. C.J. Hawker, J.M.J. Fréchet, Macromolecules 23, 4726-4729 (1990)

35. D.A. Tomalia, Z.G. Wang, M. Tirrell, Curr. Opin. Colloid Interface Sci. 4, 3-5 (1999)

36. F. Vögtle, S. Gestermann, R. Hesse, H. Schwierz, B. Windisch, Prog. Polym. Sci. 25, 987-992 (2000)

37. M. Sowinska, Z. Urbanczyk-Lipkowska, New J. Chem. 38, 21682203 (2014)

38. U. Singh, M.M. Dar, A.A. Hashmi, Orient. J. Chem. 30, 911-922 (2014)

39. D.A. Tomalia, H. Baker, J. Dewald, M. Hall, G. Kallos, S. Martin, J. Roeck, J. Ryder, P. Smith, Macromolecules 19, 2466-2468 (1986)

40. W. Zhu, B. Okollie, Z.M. Bhujwalla, D. Artemov, Magn. Reson. Med. 59, 679-685 (2008)

41. T. Kawaguchi, K.L. Walker, C.L. Wilkins, J.S. Moore, J. Am. Chem. Soc. 117, 2159-2165 (1995)

42. S. Nara, V. Tripathi, S.K. Chaube, K. Rangari, H. Singh, K.P. Kariya, T.G. Shrivastav, Talanta 77, 210-216 (2008)

43. S.M. Grayson, J.M.J. Fréchet, Chem. Rev. 101, 3819-3868 (2001)

44. E. Abbasi, S.F. Aval, A. Akbarzadeh, M. Milani, H.T. Nasrabadi, S.W. Joo, Y. Hanifehpour, K. Nejati-Koshki, R. PashaeiAsl, Nanoscale Res. Lett. 9, 247 (2014)

45. R. Abu-Reziq, H. Alper, D. Wang, M.L. Post, J. Am. Chem. Soc. 128, 5279-5282 (2006)

46. A.J. Ruiz-Sanchez, P. Mesa-Antunez, N. Barbero, D. Collado, Y. Vida, F. Najera, E. Perez-Inestrosa, Polym. Chem. 6, 30313038 (2015)
47. L. Crespo, G. Sanclimens, M. Pons, E. Giralt, M. Royo, F. Albericio, Chem. Rev. 105, 1663-1670 (2005)

48. A.W. Bosman, A.M. Janssen, E.W. Meijer, Chem. Rev. 99, 1665-1710 (1999)

49. F. Zeng, S.C. Zimmerman, Chem. Rev. 97, 1681-1730 (1997)

50. B. Klajnert, M. Bryszewska, Acta Biochim. Pol. 48, 199-208 (2001)

51. K.L. Wooley, J.M.J. Fréchet, C.J. Hawker, Polymer 35, 44894495 (1994)

52. C.J. Hawker, E. Malmström, C.W. Frank, J.P. Kampf, J. Am. Chem. Soc. 119, 9903-9911 (1997)

53. U. Gupta, H.B. Agashe, A. Asthana, N.K. Jain, Biomacromol 7, 649-658 (2006)

54. T.H. Mourey, S.R. Turner, M. Rubinstein, J.M.J. Fréchet, C.J. Hawker, K.L. Wooley, Macromolecules 25, 2401-2410 (1992)

55. E.M.M. de Brabander-van den Berg, E.W. Meijer, Angew. Chem. Int. Ed. Engl. 32, 1308-1316 (1993)

56. D. Astruc, J.-C. Blais, E. Cloutet, L. Djakovitch, S. Rigaut, J. Ruiz, V. Sartor, C. Valério, Dendrimers II, in Topics in Current Chemistry, ed. by F. Vögtle (Springer, Berlin, 2000), pp. 229-259210

57. D.K. Smith, F. Diederich, Dendrimers II, in Topics in Current Chemistry, ed. by F. Vögtle (Springer, Berlin, 2000), pp. 183-190210

58. H. Frey, C. Schlenk, , In Dendrimers II. Topics in Current Chemistry, F. Vögtle ed. (Springer, Berlin, Heidelberg, 2000) vol. 210, pp. 69-81.

59. C. Hawker, Curr. Opin. Colloid Interface Sci. 4, 117-122 (1999)

60. K. Inoue, Prog. Polym. Sci. 25, 453-462 (2000)

61. M. W. P. L. Baars, E. W. Meijer, In Dendrimers II. Topics in Current Chemistry, F. Vögtle ed. (Springer, Berlin, Heidelberg, 2000) vol. 210, pp. 131-138.

62. J.S. Moore, Curr. Opin. Colloid Interface Sci. 4, 108-116 (1999)

63. A.J. Berresheim, M. Müller, K. Müllen, Chem. Rev. 99, 17471786 (1999)

64. A.D. Schlüter, J. P. Rabe, Angew. Chem., Int. Ed. Engl., 39, 864-883 (2000)

65. O.A. Matthews, A.N. Shipway, J.F. Stoddart, Prog. Polym. Sci. 23, 1-9 (1998)

66. D. Ruth, I. Lorella, Adv. Drug Deliv. Rev. 57, 2215-2237 (2005)

67. S. G. Sampathkumar, K. J. Yarema, Dendrimers in cancer treatment \& diagnosis C. S. S.R. Kumar ed. (John Wiley \& Sons, Hoboken, NJ 2007) pp 1-47.

68. R. E. Bauer, A.C. Grimsdale, K. Müllen, In Functional Molecular Nanostructures. Topics in Current Chemistry, A. D. Schlüter (ed.) (Springer, Berlin, Heidelberg, 2005), vol. 245, pp. 253-286.

69. S. Svenson, D.A. Tomalia, Adv. Drug Deliv. Rev. 57, 2106-2129 (2005)

70. M. Fischer, F. Vögtle, Angew. Chem., Int. Ed. Engl., 38, 885-905 (1999)

71. X.-G. Lei, S. Jockusch, N.J. Turro, D.A. Tomalia, M.F.J. Ottaviani, J. Colloid Interface. Sci. 322, 457-464 (2008)

72. K.E. Broaders, S. Grandhe, J.M.J. Fréchet, J. Am. Chem. Soc. 133, 756-758 (2011)

73. V. Gajbhiye, P.V. Kumar, R.K. Tekade, N.K. Jain, Curr. Pharmaceut. Des. 13, 415-429 (2007)

74. A.Y. Lebedev, A.V. Cheprakov, S. Sakadžić, D.A. Boas, D.F. Wilson, S.A. Vinogradov, A.C.S. Appl, Mater. Interfaces 1, 1292-1304 (2009)

75. G. Pasut, F.M. Veronese, Prog. Polym. Sci. 9, 933-942 (2007)

76. E.R. Gillies, J.M.J. Fréchet, Drug Discov. Today 10, 35-43 (2005)

77. M. Maciejewski, J. Macromol. Sci. Part A : Chem. 17, 689-703 (1982)

78. J. Haensler, F.C. Szoka, Bioconjugate Chem. 4, 372-379 (1993) 
79. J.F.G.A. Jansen, E.M.M. de Brabander-van den Berg, E.W. Meijer, Science 266, 1226-1229 (1994)

80. J.F.G.A. Jansen, E.W. Meijer, E.M.M. de Brabander-van den Berg, J. Am. Chem. Soc. 117, 4417-4418 (1995)

81. M. Liu, K. Kono, J.M.J. Fréchet, J. Control. Rel. 65, 121-131 (2000)

82. C. Kojima, K. Kono, K. Maruyama, T. Takagishi, Bioconjugate Chem. 11, 910-917 (2000)

83. N. Malik, E.G. Evagorou, R. Duncan, Anticancer Drugs 10, 767-776 (1999)

84. N. Malik, R. Duncan, D .A. Tomalia, R. Esfand, "Dendriticantineoplastic drug delivery system", US 7005124 B2 (2006)

85. N. Malik and R. Duncan, "Dendritic-platinate drug delivery system", US 6585956 B2 (2003)

86. L. Balogh, D.R. Swanson, D.A. Tomalia, G.L. Hagnauer, A.T. McManus, Nano Lett. 1, 18-21 (2001)

87. J.M.J. Fréchet, Science 263, 1710-1715 (1994)

88. K.M. Kitchens, R.B. Kolhatkar, P.W. Swaan, N.D. Eddington, H. Ghandehari, Pharm. Res. 23, 2818-2826 (2006)

89. R.B. Kolhatkar, P. Swaan, H. Ghandehari, Pharm. Res. 25, 1723 1729 (2008)

90. M. Najlah, S. Freeman, D. Attwood, A. D’Emanuele, Int. J. Pharm. 336, 183-190 (2007)

91. N. Vijayalakshmi, A. Ray, A. Malugin, H. Ghandehari, Bioconjugate Chem. 21, 1804-1810 (2010)

92. R. Jevprasesphant, J. Penny, D. Attwood, A. D'Emanuele, J. Control. Rel. 97, 259-267 (2004)

93. M. El-Sayed, C.A. Rhodes, M. Ginski, H. Ghandehari, Int. J. Pharm. 265, 151-157 (2003)

94. A.T. Florence, T. Sakthivel, I. Toth, J. Control. Rel. 65, 253-259 (2000)

95. R. Wiwattanapatapee, B. Carreno-Gomez, N. Malik, R. Duncan, J. Pharm. Pharmacol. 50, 99-99 (1998)

96. N. Malik, R. Wiwattanapatapee, R. Klopschetal, J. Control. Rel. 65, 133-148 (2000)

97. R. Wiwattanapatapee, B. Carreno-Gomez, N. Malik, R. Duncan, Pharm Res. 17, 991-998 (2000)

98. D. Mullin, J. Allergy, Clin. Immunol. 112, 810-814 (2003)

99. D.A. Tomalia, Adv. Mater. 6, 529-539 (1994)

100. D.S. Wilbur, P.M. Pathare, D.K. Hamlin, K.R. Buhler, R.L. Vessella, Bioconjugate Chem. 9, 813-825 (1998)

101. N.A. Peppas, CRS Newsletter 12, 12-13 (1995)

102. S. Pearson, H. Jia, K. Kandachi, Nat. Biotechnol. 9, 3-4 (2004)

103. H.L. Fu, S.X. Cheng, X.Z. Zhang, R.X. Zhuo, J. Gene Med. 9, 1334-1342 (2008)

104. H.L. Fu, S.X. Cheng, X.Z. Zhang, J. Gene Med. 9, 181-188 (2007)

105. D. Tathagata, G. Minakshi, N.K. Jain, Vaccine 9, 3389-3394 (2008)

106. W.-D. Jang, K. M. Kamruzzaman Selim, C.-H. Lee, and I. K. Kang, Prog. Polym. Sci., 34,1-23 (2009)

107. B.P. Hay, E.J. Werner, K.N. Raymond, Bioconjugate Chem. 15, 1496-1502 (2004)

108. P. Caravan, J.J. Ellison, T.J. McMurry, R.B. Lauffer, Chem. Rev. 99, 2293-2352 (1999)

109. F.N. Franano, W.B. Edwards, M.J. Welch, M.W. Brechbiel, O.A. Gansow, J.R. Duncan, Magn. Reson. Imaging 13, 201$214(1995)$

110. E.C. Wiener, M.W. Brechbiel, H. Brothersetal, Magn. Reson. Med. 31, 1-8 (1994)

111. H. Kobayashi, S. Kawamoto, S.-K. Jo, H.L. Bryant Jr., M.W. Brechbiel, R.A. Star, Bioconjugate Chem. 14, 388-394 (2003)

112. R. Langer, J.P. Vacanti, Science 260, 920-926 (1993)

113. R. Langer, D.A. Tirrell, Nature 428, 487-492 (2004)

114. M.P. Lutolf, J.A. Hubbell, Nat. Biotechnol. 23, 47-55 (2005)

115. J. Glowacki, S. Mizuno, Biopolymers 89, 338-344 (2008)
116. T. A. E. Ahmed, E. V. Dare, M. Hincke, Tissue Eng.: Part B Rev., 14, 199-215 (2008)

117. D.L. Nettles, T.P. Vail, M.T. Morgan, M.W. Grinstaff, L.A. Setton, Ann. Biomed. Eng. 32, 391-397 (2004)

118. Q. Li, C.G. Williams, D.D.N. Sun, J. Wang, K. Leong, J.H. Elisseeff, J. Biomed. Mater. Res. 68, 28-33 (2004)

119. A.D. Augst, H.J. Kong, D.J. Mooney, Macromol. Biosci. 6, 623-633 (2006)

120. M.P. Bajgai, S. Aryal, S.R. Bhattarai, K.C.R. Bahadur, K.W. Kim, H.Y. Kim, J. Appl. Polym. 108, 1447-1454 (2008)

121. S.G. Lèvesque, M.S. Shoichet, Bioconjugate Chem. 18, 874885 (2007)

122. T. Jiang, S.G. Kumbar, L.S. Nair, C.T. Laurencin, Curr. Top. Med. Chem. 8, 354-364 (2008)

123. J.L. Ifkovits, J.A. Burdick, Tissue Eng. 13, 2369-2385 (2007)

124. C.P. Barnes, S.A. Sell, E.D. Boland, D.G. Simpson, G.L. Bowlin, Adv. Drug Deliv. Rev. 59, 1413-1433 (2007)

125. A. Atala, J. Endourol. 14, 49-57 (2000)

126. N. Joshi, M. Grinstaff, Curr. Top. Med. Chem. 8, 1225-1236 (2008)

127. J.C.Y. Chan, K. Burugapalli, H. Naik, J.L. Kelly, A. Pandit, Biomacromol 9, 528-536 (2008)

128. J.B. Wolinsky, M.W. Grinstaff, Adv. Drug Deliv. Rev. 60, 1037-1055 (2008)

129. K.A. Boduch-Lee, T. Chapman, S.E. Petricca, K.G. Marra, P. Kumta, Macromolecules 37, 8959-8966 (2004)

130. S.H.E. Kaufmann, Nat. Rev. Microbiol. 5, 491-504 (2007)

131. P.M.H. Heegaard, U. Boas, N.S. Sorensen, Bioconjugate Chem. 21, 405-418 (2010)

132. J. P. Tam,“Multiple antigen peptide system,"US5229490A (1993)

133. C.Y. Wang, D.J. Looney, A.M. Walfieldetal, Science 254, 285 $288(1991)$

134. J.P. Tam, Y.-A. Lu, Proc. Natl. Acad. Sci. USA 86, 9084-9088 (1989)

135. H. Baigude, K. Katsuraya, K. Okuyama, T. Uryu, Macromol. Chem. Phys., 684-691 (2004)

136. M. Zaman, M. Skwarczynski, J.M. Malcol, Met. Nanomed.Nanotechnol. 7, 168-173 (2011)

137. R. Wang, Y. Charoenvit, G. Corradin, R. R. Porrozzi, R. L. Hunter, G. Glenn, C. R. Alving, P. Church, S. L. Hoffman., J. Immunol.,155, 1637-1641 (1995)

138. S. Ota, T. Ono, A. Morita, A. Uenaka, M. Harada, E. Nakayama, Cancer Res. 62, 1471-1476 (2002)

139. R. Cañas-Arranz, M. Forner, S. Defaus, P. de León, M. J. Bustos, E. Torres, F. Sobrino, D. Andreu, E. Blanco, Vaccines, 8(1), p.19 (2020)

140. S. R. Bonam, A. Areti, P. Komirishetty, S. Muller, In Pharmaceutical Applications of Dendrimers (Elsevier, 2020), pp. 233-249.

141. A. Santos, F. Veiga, A. Figueiras, Materials, 13(1), p.65. (2020)

142. N. Pardi, M.J. Hogan, D. Weissman, Curr. Opin. Immunol. 65, 14-20 (2020)

143. G.D. Zhang, A. Harada, N. Nishiyama, D.-L. Jiang, H. Koyama, T. Aida, K. Kataoka, J. Control. Rel. 93, 141-150 (2003)

144. S.H. Battah, C.E. Chee, H. Nakanishi, S. Gerscher, A.J. MacRobert, C. Edwards, Bioconjugate Chem. 12, 980-988 (2001)

145. W.S. Li, T. Aida, Chem. Rev. 109, 6047-6076 (2009)

146. A. Narsireddy, K. Vijayashree, M.G. Adimoolam, S.V. Manorama, Int. J. Nanomedicine 10, 6865-6878 (2015)

147. B. Klajnert, M. Rozanek, M. Bryszewska, Curr. Med. Chem. 19, 4903-4912 (2012)

148. L. Chong, F. Aydin, M. Dutt, J. Comput. Chem. 37, 920-926 (2015)

149. J. W. J. Knapen, A. W. vander Made, J. C. de Wilde, P. W. N. M. van Leeuwen, P. Wijkens, D. M. Grove, G. van Koten, Nature, 372, 659- 663 (1994) 
150. H. Brunner, J. Organomet. Chem. 500, 39-50 (1995)

151. N.G. Connelly, W.E. Geiger, Chem. Rev. 96, 877-910 (1996)

152. I. Cuadrado, M. Moran, C.M. Casado, B. Alonso, J. Losada, Coord. Chem. Rev. 395, 193-195 (1999)

153. H.J. Han, R.M. Kannan, S. Wang, G. Mao, J.P. Kusanovic, R. Romero, Adv. Funct. Mater. 20, 409-421 (2010)

154. D. Astruc, J.-R. Hamon, G. Althoff, E. Roman, P. Batail, P. Michaud, J.-P. Mariot, F. Varret, D. Cozak, J. Am. Chem. Soc. 101, 5445-5447 (1979)

155. A. Miedaner, C.J. Curtis, R.M. Barkley, D.L. DuBois, Inorg. Chem. 33, 5482-5490 (1994)

156. M. Zhao, B. Helms, E. Slonkina, S. Friedle, D. Lee, J. DuBois, B. Hedman, K.O. Hodgson, J.M.J. Fréchet, S.J. Lippard, J. Am. Chem. Soc. 130, 4352-4363 (2008)

157. T. Magbitang, V. Y. Lee, J. N. Cha, H. L. Wang, W. R. Chung, R. D. Miller, G. Dubois, W. Volksen, H.-C. Kim, J. L. Hedrick, Angew. Chem., Int. Ed. Engl., 44, 7574-7580 (2005)

158. E. Boisselier, A.K. Diallo, L. Salmon, C. Ornelas, J. Ruiz, D. Astruc, J. Am. Chem. Soc. 132, 2729-2742 (2010)

159. D. Astruc, K. Heuze, S. Gatard, D. Mery, S. Nlate, L. Plault, Adv. Syn. Catal. 347, 329-338 (2005)

160. L. Liang, J. Ruiz, D. Astruc, J. Inorg. Organomet. Polym. Mater. 20, 503-510 (2010)

161. D. Astruc, Acutal. Chim. 7(8), 3-12 (2001)

162. P.P. Zweni, H. Alper, Adv. Syn. Catal. 348, 725-731 (2006)

163. R. Touzani, H. Alper, J. Mol. Cat. A: Chem. 227, 197-207 (2005)

164. R. Chanthateyanonth, H. Alper, J. Mol. Cat. A: Chem. 201, 23-31 (2003)

165. S.-M. Lu, H. Alper, J. Am. Chem. Soc. 127, 14776-14784 (2005)

166. S.-M. Lu, H. Alper, Chem. Eur. J. 13, 5908-5916 (2007)

167. D. A. Tomalia, J. M .J. Fréchet, J. Polym. Sci., Part A: Polym. Chem., 40, 2719-2728 (2002)

168. W.C. Floyd, P.J. Klemm, D.E. Smiles, A.C. Kohlgruber, V.C. Pierre, J.L. Mynar, J.M.J. Fréchet, K.N. Raymond, J. Am. Chem. Soc. 133, 2390-2393 (2011)

169. N. Launay, A. M. Caminade, R. Lahana, J. P. Majoral, Angew. Chem., Int. Ed. Engl., 33 1589-1592 (1994)

170. G.R. Newkome, E. He, C.M. Moorefield, F. Vögtle, Dendrimers and Dendrons (Concepts, Synthesis, Applications, Wiley VCH, Weinhein, 2001)
171. G.R. Newkome, C.D. Shreiner, Chem. Rev. 110, 6338-6442 (2010)

172. C. Wörner, R. Mülhaupt, Angew. Chem,. Int. Ed. Engl., 32, 13061308 (1993)

173. A. Nantalaksakul, R.R. Dasari, T.-S. Ahn, R. Al-Kaysi, C.J. Bardeen, S. Thayumanavan, Org. Lett. 8, 2981-2984 (2006)

174. H. Q. Peng, Y. Z. Chen, Y. Zhao, Q. Z. Yang, L. Z. Wu, C. H. Tung, L.P. Zhang, Q. X. Tong, Angew. Chem., Int. Ed. Engl., 51, 2088-2092 (2012)

175. F. M. Winnick, J. M. Duff, G. G. Sacripante, A. R. Davidson, (Xerox Corp.), USA 5256516 A 931026 (1993), Chem. Abstr. 120, 90707i (1994)

176. M. Diallo, S. Christie, P. Swaminathan, J. Johnson, W. Goddard, Environ. Sci. Technol. 39, 1366-1377 (2005)

177. Y.H. Xu, D.Y. Zhao, Environ. Sci. Technol. 39, 2369-2375 (2005)

178. S.M. Cohen, S. Petoud, K.N. Raymond, Chem. Eur. J. 7, 272-279 (2001)

179. A. Rether, M. Schuster, React. Funct. Polym. 57, 13-21 (2003)

180. M. Arkas, D. Tsiourvas, C.M. Paleos, Chem. Mater. 15, 28442847 (2003)

181. G. Pistilis, A. Malliaris, Langmuir 18, 246-251 (2002)

182. W.W.H. Wong, C.-Q. Ma, W. Pisula, C. Yan, X.L. Feng, D.J. Jones, K. Mullen, R.A.J. Janssen, P. Bauerle, A.B. Holmes, Chem. Mater. 22, 457-466 (2010)

183. J. Lu, P.F. Xia, P.K. Lo, Y. Tao, M.S. Wong, Chem. Mater. 18, 6194-6203 (2006)

184. O. Mongin, T. R. Krishna, M. H. V. Werts, A.-M. Caminade, J.-P .Majoral, M. Blanchard-Desce, Chem. Commun., 915-917 (2006)

185. D.A. Tomalia, Sci. Am. 272, 42-46 (1995)

186. M. Lard, S.H. Kim, S. Lin, P. Bhattacharya, P.C. Ke, M.H. Lamm, Phys. Chem. Chem. Phys. 12, 9285-9291 (2010)

187. C. J. Wilson, D. A. Wilson, A. E. Feiring, V. R. Percec, V. Diana, J. Polym. Sci., A: Polym. Chem., 48, 2498-2502 (2010)

188. J. Giri, M.S. Diallo, W.A. Goddard, N.F. Dalleska, X. Fang, Y. Tang, Environ. Sci. Technol. 43, 5123-2129 (2009)

189. X.-Z. Wei, L.-P. Zhu, H.Y. Deng, Y.Y. Xu, B.-K. Zhu, Z.-M. Huang, J. Membr. Sci. 323, 278-287 (2008) 